\title{
Identification And Classification of Behavioural Indicators to Assess Innovation Competence
}

\author{
María José Pérez-Peñalver iD, Lourdes E. Aznar-Mas iD, Begoña Montero-Fleta iD \\ Universitat Politècnica de València (Spain) \\ mjperez@mat.upv.es, laznan@idm.upv.es,bmontero@idm.upv.es
}

Received: December 2017

Accepted: February 2018

\begin{abstract}
:
Purpose: Taking a literature review as a point of departure, the main aim of this paper was the identification of the behavioural indicators of innovators at the workplace, and their classification.

Design/methodology/approach: A literature review was addressed by means of a search in Elsevier's Scopus, Web of Science and Google Scholar. By applying inclusive and exclusive criteria, references were obtained with the search protocol. After filtering and scanning, there was a selection of references plus other articles added by the snowball effect. The final phase undertaken was the classification of the main indicators raised in the publications selected.
\end{abstract}

Findings: Our main contribution was the identification of the behavioural indicators of innovators at the workplace and their classification in five dimensions.

Practical implications: This research may yield some light on the assessment of innovative workplace performance of individuals in organisations, as well as on the development of the innovative competence of students in academic institutions as a challenge to meet the needs of both professionals and Higher Education institutions.

Originality/value: Some authors have studied the characteristics of innovative people mainly focusing on cognitive abilities, personality, motivation and knowledge. We have sought to offer a better understanding of the phenomenon of individual innovation in organisations, through the analysis of behavioural indicators, an issue that has not been studied from this perspective previously.

Keywords: individual innovation, innovative work behaviour, behavioural indicators, literature review, soft competencies, innovation management in operations

\section{Introduction}

Organizations and companies need to meet the challenges of a competitive and globalised 21 st century if they want to develop sustainability and continue to grow. It is necessary for them to possess the driver for change that makes them different from the rest. Innovation, as a key determinant of company competitiveness (Amabile, 1988; Pérez-Peñalver, Aznar-Mas \& Watts, 2012), has led social scientists and psychologists to discuss how organizational innovation can be promoted (De Spiegelaere, Van Gyes, Van Thillo \& Van Hootegem, 2012). It has recently been recognised that employees are crucial drivers for this innovation (Agarwal, 2014; Anderson, Potočnick \& Zhou, 2014; De Spiegelaere et al., 2012; De Spiegelaere, Van Gyes \& Van Hootegem, 2016; Kör, 2016; Odoardi, 2015; Patterson, Kerrin, Gatto-Roissard \& Coan, 2009). 
Whereas not many individuals in organizations are able to think outside the box and show their openness because they are averse to taking risks (Parzefall, Seeck \& Leppänen, 2008), others show a positive mood towards innovative behaviour and participate in the implementation of any novelty (Frese \& Fay, 2001; Madrid, Patterson, Birdi, Leiva \& Kausel, 2014). There is a lot of talent among these people (Marin-Garcia, Aznar-Mas \& González-Ladrón de Guevara, 2011) and companies need to manage it, as the success of many organizations may be in the hands of these innovators (Ferruzca-Navarro, Rodrigues-Martínez, Monguet-Fierro \& Trejo-Omeñaca, 2013; GonzalezLadrón de Guevara, Watts, Andreu-Andrés, Aznar-Mas, Fernández, García-Carbonell et al., 2011; Odoardi, 2015). This is the reason why organizations are trying to recruit this type of individuals who will promote change with broader perspective (Giebels, de Reuver, Rispens \& Ufkes, 2016), and will increase competitiveness (Bălău, Faems \& van der Bij, 2012; Zhu, Djurjagina \& Leker, 2014).

\section{Justification and Aims of the Study}

Some scholars have complained about the fact that individual innovative behaviour has been underestimated for a long time in the literature and, hence, the need of further research (Anderson et al., 2014; Bălău et al., 2012; Hakimian, Farid, Ismail \& Nair, 2016; Hammond, Neff, Farr, Schwall \& Zhao, 2011; Nelson, Brice \& Gunby, 2010; Patterson et al., 2009). Interestingly, the literature on individual innovation has expanded with increasing scholarly publications from the year 2000 up to now, as shown below in Figure 1, thus the reason for the rank established in our search.

Evolution of scholarly research publications

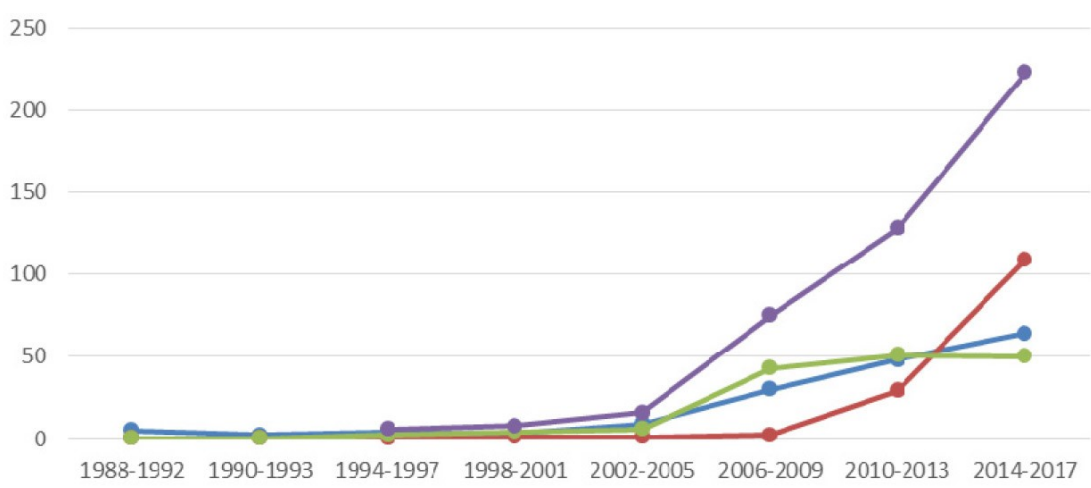

$\multimap$ Individual Innovation $\multimap$ Innovative work bchaviour $\longrightarrow$ Innovation compcten* $\multimap$ Sum

Figure 1. "Individual Innovation”, 165 hits; "Innovative Work Behaviour” (IWB), 142 hits; "Innovation competen*”, 156 hits. Search made after title, abstract and keywords (January 2018) (Scopus, 1988-2017)

However, the topic still merits further research. The main aims of our study are to find in the existing literature the indicators associated to innovators and their classification. This classification is expected to shed some light on questions such as: How can innovators be detected? Which are the predictors of innovative behaviour in employees? A systematic literature review will be the point of departure of our study. This classification into categories can be relevant to detect and measure the innovative abilities at the individual level.

The behavioural indicators pursued in this study are observable traits of a specific attitude that can be assessed. Thus, this paper strives to address a better understanding of the dimensions and indicators involved in the innovation of employees at the workplace and it seeks to establish a framework to allow the design of adequate assessment tools either for self-assessment and/or external assessment. 


\section{Previous Literature Reviews}

Some literature reviews arisen through our research on innovation at the workplace are very general and mainly concentrate on the state of the art and future directions (Anderson et al., 2014; Zhou \& Shalley, 2003). Anderson et al. (2014) proposed an integrative definition of creativity and innovation and offered theoretical perspectives to creativity at the workplace and innovation from the point of view of componential or individual creative action, among others.

Other reviews have studied the antecedents of innovation and creativity, innovation at the level of individual, teams and organizations (Anderson et al, 2014; Caniëls, De Stobbeleir \& De Clippeleer, 2014; Parzefall et al., 2008). Some scholars have studied innovation based only on teamwork (Hülsheger, Anderson \& Salgado, 2009). De Spiegelaere, Van Gyes and Van Hootegem (2014) have highlighted the concept of innovative work behaviour (IWB), its dimensions and other related aspects. Meta-analyses on the relationship of factors predicting innovation have been published (Hammond et al., 2011), and new models (Ramamoorthy, Flood, Slattery \& Sardessai, 2005) with the framework of the relationship between IWB and other variables have also been carried out.

Most recent systematic literature reviews by Bos-Nehles, Renkema and Janssen (2017) and Li and Hsu (2016) have studied the link between human resource practices and IWB at the employee level. Some scholars have focused on the concept of intrapreneurship in working life, e.g., Wiethe-Körprich, Weber, Bley and Kreuzer (2017) and De Jong (2016). Some insight into the impact of learning behaviours on innovative behaviour in work teams has been the concern of scholarly research run by Widmann, Messmann and Mulder (2016). Lukeš and Stephan (2017) have developed an integrative model and validate a tool to assess employee innovation.

However, not many review studies have tackled innovation from an individual perspective, although there is an increasing interest in the topic. Hence, the need of a comprehensive framework that identifies the individual characteristics of innovation.

Some authors have undertaken reviews laying emphasis on the characteristics of innovative people (Bălău et al., 2012; Hammond et al., 2011; Patterson et al., 2009), these have mainly focused on cognitive abilities, personality, motivation and knowledge (Batra \& Vohra, 2016).

\section{Layout of the Present Study}

After the introduction and justification above, the reader can first find the method used in the literature review. Secondly, our research will address the differences between the concepts of innovation and creativity; next, concepts related with individual innovation will be revised and some models will be presented. The study will also include the integrative feature of a model regarding the literature reviewed. Finally, our classification of behavioural indicators of innovation will be devised.

\section{Methodology}

\subsection{Search Protocol Process}

In order to fulfil the objectives of this study, a group of three researchers worked together on a systematic literature review. The main aim of this literature review was the identification of the behavioural indicators of innovators at the workplace, and their classification.

There was a first general scan of the literature via the Internet; then a series of specific keywords were agreed to be used in the search protocol so as to identify the indicators associated to the innovative behaviour of employees:

- workplace: employment, work, company, organization;

- innovative behaviour, innovative work behaviour and individual innovation;

- indicators: markers, patterns, descriptors, components, characteristics, factors, observations, parameters, determinants.

The publications searched were to be written in English from 2000 to June 2015, and indexed in the databases agreed. The most relevant literature prior to 2000 was included in the selection by the snowball process. Inclusive and exclusive criteria were clearly defined to reduce the vast number of research published during the period of 
study. The publications had to be related to theoretical studies, journal articles, dissertations, literature reviews, meta-analyses and experimental or quasi-experimental studies. The exclusive criteria corresponded to studies related to the observation of particular psychological behaviour, other areas of Social Sciences and organizational innovation.

The databases accessed were Elsevier's Scopus, Web of Science and Google Scholar, which offer extensive abstracts and citation databases, peer-reviewed literature, reliable multidisciplinary research and indexed work. The total number of references obtained was 2,264.

The results of the search yielded 754 references retrieved from Elsevier's Scopus, 773 from Web of Science, and 737 from Google Scholar. Concerning Google Scholar, only 200 references were finally selected by relevance and date of publication. Further details on the search protocol can be found in Montero-Fleta, Pérez-Peñalver and Aznar-Mas (2017).

Once all references had been saved and organised with Mendeley, a reference manager software tool, the results were merged and duplicates were removed. Additionally, a number of studies not closely related, from the researchers' point of view, were discarded. Other false negative studies were incorporated by using the agreed criteria; thus, the number of references selected was reduced to 1,383 .

There was a first phase in which the three researchers worked together in a screening of title and abstract of all articles to find evidences of significant details for the research being undertaken. In this phase, 115 articles were scanned in a joint session by the three researchers, to verify that there were no discrepancies according to the following selection criteria: experimental studies, impact, studies including questionnaires on individual innovation at the workplace, publications dealing with behavioural indicators of individual innovation the workplace. Next, the titles and abstracts of the 1,383 articles previously selected were distributed to be read by the three researchers with an overlapping of a $10 \%$.

The second phase was the individual reading of the selected articles where those relevant for our research were saved. The labelling of articles identified those fitting any of the selection criteria. The total number of articles selected was 222 plus other 90 articles added by the snowball effect, then yielding a final number of 312 articles read by the three researchers.

As the publication of the present paper has been delayed, we have found it convenient to update the search and add the most relevant references published in the years 2016 and 2017. Among the most cited publications in these years, 28 were read.

A classification of the main indicators raised in the publications chosen was finally undertaken.

\subsection{Methodology Used in the Design of the Model}

To devise the model of individual innovation competence the participation of members of a research group and Human Resources managers of multinational companies was required. Three group dynamics discussed the available material:

- Research group.

Purpose: to devise a preliminary model, based on existing models found through the systematic literature review undertaken.

- Four members of the research group, three Human Resources managers and one person in charge of innovation working for two multinational companies located in Spain.

Purpose: to redesign the model and divide it into phases.

- A workshop with a new work group made up of nine researchers from other European partner universities and 17 managers from nine European innovative medium- and large-sized companies.

Purpose: to discuss and finally agree the model and the definition of its dimensions. 


\section{Conceptual Framework of the Study}

\subsection{Behavioural Indicators and Behavioural Assessment}

An issue of special concern is the statement of the most appropriate behavioural indicators to assess innovation. Behavioural assessment is deals with "clearly observable aspects in the way a person interacts with his or her environment" (Groth-Marnat, 2009: page 103). This observable feature is a behavioural indicator that shows the presence of a particular competence (Dent \& Krefft, 2004) or evidences the degree of development of a competence (Cruz-Serna., Orozco-Jaramillo, Varela-Gaviria, Trespalacios-Bustos, Zapata-Arboleda, Bustamante-Osorio et al., 2012). Then, the descriptors sought have to be observable and measurable behaviours to allow for a better assessment of staff performance and, thus, of their management and development (Muchinsky, 2006). The more behavioural indicators appear during, e.g., an interview, the greater the likelihood for the candidate to be strong in a particular competence (Dent \& Krefft, 2004).

Behavioural assessment focuses on issues such as why target behaviours occur, how behaviours should be measured, or what levels of analysis, possibility of change and complexity are preferred (Aznar-Mas, Pérez-Peñalver, Montero-Fleta, González-Ladrón de Guevara, Marin-Garcia \& Atarés-Huerta, 2016). These assumptions are obvious in the use of specific assessment procedures that have been designed to yield data from well-defined and validated measures of target behaviours and contextual variables for an individual client (O'Brien, Oemig \& Northern, 2010). Furthermore, behavioural assessment also fosters the design of the measuring instruments that can be validated and standardised, thus reducing the subjectivity of the process of staff assessment (Arias-Galicia \& Heredia-Espinosa, 2006).

\subsection{Key Concepts: Innovation and Creativity}

Innovation and creativity, two terms frequently considered synonyms have, thus, been often used interchangeably not only by organisations but also by researchers (Carmeli, Meitar \& Weisberg, 2006; Scott \& Bruce, 1994). These apparently overlapping concepts often lead to a misunderstanding regarding outcomes in organisational innovation (Patterson et al., 2009). Yet, although creativity is central to the whole innovation process, its difference from innovation is clearly highlighted by scholars (Amabile, 1983; Anderson et al., 2014; Ng \& Feldman, 2013a, 2013b; Patterson et al., 2009; Scott \& Bruce, 1994; Shalley, Gilson \& Blum, 2009, to name only a few).

For Scott and Bruce (1994), creativity is doing something for the first time anywhere or creating new knowledge. The idea of novelty is present in most definitions of creativity. According to Amabile (1983, 1996), creativity generates new and entirely original ideas and is a previous step, a prerequisite or a starting point for innovation. Furthermore, creative work must be not only novel but also appropriate (Messmann \& Mulder, 2011). Thus, apart from the idea of novelty, applicability is also addressed when defining creativity. In this line of thought, Baer (2012) asserts that creativity implies not only the generation of ideas but also that these ideas meet the criteria of novelty and usefulness. There seems to be a general agreement on the application of employee creativity to the production of ideas, products, services, processes or procedures that, besides novel and original, are potentially useful to the employing organization (Amabile, 1983, 1996; Carmeli, Reiter-Palmon \& Ziv, 2010; De Jong \& Den Hartog, 2008; Kim, Hon \& Crant, 2009; Woodman, Sawyer \& Griffin, 1993). However, some scholars discard this latter perspective of usefulness and define creativity as the mental process and the ability to generate new ideas independently of their possible practicability and future added value (Cerinšec \& Dolinšek, 2009).

The considerations set out in the previous paragraphs clearly relate creativity with the generation of ideas, i.e., the creative stage of the process. This is in sharp contrast with the actual concept of innovation, which involves the subsequent stage of implementation of these ideas toward better procedures, practices, or products (Anderson et al., 2014). Thus, whereas creativity has to do with production, innovation can be seen as a successful implementation of creativity (Scott \& Bruce, 1994), a distinction which leads some scholars support that the foundation of innovation ideas is creativity (De Spiegelaere et al., 2012; Janssen, 2000; Ng \& Feldman, 2013a, 2013b; Slåtten \& Mehmetoglu, 2011 based on Van de Ven, 1986). But although every innovation requires creativity, creativity does not necessarily lead to innovation. To develop and introduce new and improved ways of doing things, both creativity and innovation are needed. 
Generally speaking, there seems to be a current trend making innovation encompass both the proposal and applications of new ideas (West \& Farr, 1990). Employee innovativeness can, thus, be argued to cover a broader range of behaviours than creativity (Parzefall et al., 2008). Innovation is a wider extensive concept (Anderson et al., 2014; Patterson, Kerrin \& Gatto-Roisard, 2015), as it encompasses both creativity, e.g., the generation or proposal of new ideas, and also the implementation or application of new ideas, all aimed at improving organizational performance (Axtell, Holman, Unsworth, Wall, Waterson \& Harrington, 2000; Carmeli et al., 2006; Janssen \& Van Yperen, 2004; Kanter, 1988; Scott \& Bruce, 1994; Van de Ven, 1986; West, 2002; West \& Farr, 1989, 1990). Nevertheless, although research literature used this inclusive two-component concept of innovation, the need to distinguish creativity from innovation implementation is often claimed (Birdi, Leach \& Magadley, 2014).

Another issue of general concern is that creativity is carried out individually but it is innovation what is carried out as a result of cooperation because of the difficulty involved in innovating alone (Waychal, Mohanty \& Verma, 2011). Innovation implies the transformation of individual work roles and the implementation of new ideas in work groups or teams (Anderson \& West, 1998; Rank, Pace \& Frese, 2004). Innovation is actually characterised by discontinuous activities rather than discrete, sequential stages (Schroeder, Van de Ven, Scudder \& Polley, 1989). Individuals can be expected to be involved in any combination of these behaviours at any one time. In this concern, Anderson et al. (2014) assert that creativity and innovation can occur at the level of the individual, team, organization, or at more than one of these levels combined, but will invariably result in identifiable benefits at one or more of these levels of analysis.

Based on the existing literature, Marin-Garcia, Andreu-Andrés, Atarés-Huerta, Aznar-Mas, García-Carbonell, González-Ladrón de Guevara et al., (2016: page 121) define creativity as:

Creativity is the ability to transcend (think beyond) traditional ideas, rules, patterns or relationships, and to generate or adapt meaningful alternatives, ideas, products, methods or services, independently of their possible practicality and future added value

Furthermore, interestingly, the integrative definition of innovation from Marin-Garcia et al., (2016: page121) is:

Innovation is the introduction of a novelty (an idea, a method, a device, an invention, a process) or the improvement of something that already exists that must be useful to people or organizations as added value to meet their needs

This view is backed by extensive research evidence demonstrating the "intentional introduction and application within a role, group or organization of ideas, processes, products or procedures, new to the relevant unit of adoption, designed to significantly benefit the individual, the group, the organization or wider society" (West \& Farr, 1990: page 9). This definition is consistent with Amabile (1988) and Birdi et al. (2014). To fully understand employee innovation, some closely related concepts will be discussed in the next section and some innovation models will be provided.

\subsection{Individual Innovation}

The literature on the characteristics of innovators in organizations uses different names for their identification, e.g., innovative behaviour, innovation competence, individual innovation, innovation-related behaviours, employee creativity and employee innovation behaviour (Amo, 2006; Cerinšek \& Dolinšek, 2009; De Jong \& Den Hartog, 2007; De Spiegelaere et al., 2012; Li \& Hsu, 2016; Lukeš \& Stephan, 2017; Marin-Garcia, Pérez-Peñalver \& Watts, 2013; Ng \& Feldman, 2013a, 2013b; Oldham \& Cummings, 1996; Scott \& Bruce, 1994; Waychal et al., 2011). It is commonly agreed that innovative behaviours constitute an extra-role behaviour in most jobs, which means individuals receive no immediate reward for their initiative and do not invoke sanctions if they do not do so (Agarwal, 2014; Janssen, 2000, 2004; Thurlings, Evers \& Vermeulen, 2014). Thus, the first and most important concept defining the characteristics and indicators of innovative people is Innovative Work Behaviour (IWB), a term created by Scott \& Bruce in 1994; since then the literature on IWB has grown steadily. Scott \& Bruce (1994) devised a fuzzy concept of IWB that referred to various stages, i.e., generation, promotion, and application of new 
ideas intended in the work role, group or organization to improve organizational performance (Abbas \& Raja, 2015; Chughtai, 2013; Janssen, 2001; Kanter, 1988; Scott \& Bruce, 1994).

IWB has also been identified with West \& Farr's (1990) definition of innovation above given (Kleysen \& Street, 2001; Reuvers, van Engen, Vinkenburg \& Wilson-Evered, 2008; Yuan \& Woodman, 2010). IWB has also been scholarly defined as a multiple-stage process in which new ideas are generated, created, developed, applied, promoted, realised, and modified by employees in order to benefit the organization or parts within it (Carmeli et al., 2006; Thurlings et al., 2014).

Whereas the authors above mentioned centred on the different stages, some research has focused on behaviours and has identified IWB as a multi-dimensional, overarching construct that captures all behaviours through which employees can contribute to the innovation process (De Jong \& Den Hartog, 2007). Although the discussion on the IWB concept has not been settled (De Spiegelaere et al., 2014), the authors of the present study agree with the latter interpretation by De Jong \& Den Hartog (2007), and support that "innovative work behaviour is all employee behaviour aimed at the generation, introduction and/or application (within a role, group or organisation) of ideas, processes, products or procedures, new and intended to benefit the relevant unit of adoption" (De Spiegelaere et al., 2014: page144).

A second point of concern refers to the different dimensions of the IWB concept. Most scholarly research suggests that IWB is not a one-dimensional construct but refers to multiple, distinguishable innovative behaviours based on the phases of the innovation process. Some authors refer to two IWB dimensions (De Jong \& Den Hartog, 2007; Yuan \& Woodman, 2010). Yet, most suggest three dimensions (Carmeli et al., 2006; Janssen, 2000; Messmann \& Mulder, 2011; Reuvers et al., 2008; Scott \& Bruce, 1994). A four-dimension IWB construct (e.g., De Jong \& Den Hartog, 2010), or even a five-dimension IWB construct (e.g., Kleysen \& Street, 2001) have also been provided. It is striking that researchers rarely manage to empirically distinguish these theoretical dimensions and IWB instruments are built on the assumption of finding dimensions related to the different phases of the innovation process. Finally, while some researchers consider IWB as a one-dimensional construct (Janssen, 2000; Scott \& Bruce, 1994), some authors see these constructs not necessarily the most appropriate ones, and demand future research to look for alternatives (Caniëls et al., 2014; De Spiegelaere et al., 2012, 2014). Table 1 shows different models that present the dimensions involved in IWB in the literature reviewed.

\begin{tabular}{|c|c|c|c|c|c|}
\hline \multicolumn{5}{|c|}{ Innovative Work Behaviour (IWB) } & \\
\hline \multirow{2}{*}{\multicolumn{3}{|c|}{$\begin{array}{l}\text { Idea generation } \\
\text { (Ideation) }\end{array}$}} & \multicolumn{2}{|c|}{$\begin{array}{l}\text { Idea implementation } \\
\text { (Application behaviour) }\end{array}$} & $\begin{array}{l}\text { e. g., De Jong and Den } \\
\text { Hartog (2007) }\end{array}$ \\
\hline & & & \multirow{2}{*}{$\begin{array}{c}\text { Idea } \\
\text { promotion }\end{array}$} & \multirow{2}{*}{$\begin{array}{l}\text { Idea realization } \\
\text { Idea realization }\end{array}$} & e. g., Scott and Bruce (1994) \\
\hline Problem & cognition & Idea generation & & & $\begin{array}{l}\text { e.g., De Jong and Den Hartog } \\
\text { (2010) }\end{array}$ \\
\hline $\begin{array}{l}\text { Opportunity } \\
\text { Exploration }\end{array}$ & Generativity & Formative Investigation & Championing & Application & e.g., Kleysen and Street (2001) \\
\hline \multicolumn{3}{|c|}{ Creative-oriented Work Behaviour } & \multicolumn{2}{|c|}{$\begin{array}{c}\text { Implementation-oriented Work } \\
\text { Behaviour }\end{array}$} & $\begin{array}{c}\text { Dorenbosch, van Engen and } \\
\text { Verhagen }(2005)\end{array}$ \\
\hline
\end{tabular}

Table 1. Models of Innovative Work Behaviour

On the other hand, another related concept probably for the implementation phase, is intrapreneurship. This concept was borne out by Pinchot (1985) and is defined as the identification and exploitation of opportunities by individual workers to advance their organization, which is generally characterized by employees' innovation, proactive and risk-taking behaviours (De Jong, 2016), where individuals, intrapreneurs, will "champion" new ideas from development to complete a profitable reality. Such people feel the need to exercise skills in obtaining and using power in order to accomplish innovation (Cerinšec \& Dolinšek, 2009). 
Wiethe-Körprich et al. (2017) associate innovative behaviour with intrapreneurship competence, a construct which is directed towards individuals' innovative work behaviour with regard to the recognition of opportunities for improvements, the generation of innovative project ideas, and the championing and implementation of such projects within the organisational practice.

From the models above, Dorenbosch et al. (2005) is of particular interest to our study. Its two main macro-phases for the innovation process, generation (Creative-oriented Work Behaviour) and implementation (Implementation-oriented Work Behaviour) have been of general agreement in the scientific community on the subject. The first phase to take place is the idea generation phase, i.e., the creativity phase, without which, innovation is impossible. Lipponen, Bardi and Haapamäki (2008) call it suggestion-making phase, a fundamental phase to innovation that can be accomplished by any employee. The second phase refers to the promotion of novel ideas that are applied within the organization.

Several representative models on workers' innovation in organizations have been devised, as the ones shown in Table 2 below. These models may explicitly describe the abilities characterising an innovative person:

\begin{tabular}{|c|c|c|c|c|c|c|c|}
\hline \multicolumn{7}{|c|}{ Individual Innovation } & \\
\hline \multicolumn{2}{|c|}{$\begin{array}{c}\text { Ability to } \\
\text { Conceptualize }\end{array}$} & \multicolumn{2}{|r|}{ Creativity } & Risk-taking & \multicolumn{2}{|c|}{ Visioning } & Evers (2005) \\
\hline \multicolumn{7}{|c|}{ Creativity $\cap$ Entrepreneurship } & $\begin{array}{l}\text { Cerinšek and Dolinšek } \\
\qquad(2009)\end{array}$ \\
\hline \multicolumn{2}{|c|}{ Creating Future } & & Reflecting & Dialoguing & \multicolumn{2}{|c|}{ Organizing } & $\begin{array}{l}\text { Derksen, de Caluwé and } \\
\text { Simons (2011) }\end{array}$ \\
\hline \multicolumn{3}{|c|}{ Creativity } & \multicolumn{2}{|c|}{ Entrepreneurial Abilities } & \multicolumn{2}{|c|}{$\begin{array}{l}\text { Achievement } \\
\text { orientation }\end{array}$} & Waychal et al. (2011) \\
\hline \multirow{2}{*}{\multicolumn{3}{|c|}{ Personal }} & \multirow{2}{*}{\multicolumn{2}{|c|}{ Interpersonal }} & \multicolumn{2}{|c|}{ Network } & $\begin{array}{l}\text { Kairisto-Mertanen, } \\
\text { Räsänen, Lehtonen and } \\
\text { Lappalainen, (2012) }\end{array}$ \\
\hline \multirow{2}{*}{\multicolumn{2}{|c|}{ Generating Ideas }} & \multirow{2}{*}{\multicolumn{2}{|c|}{$\begin{array}{c}\text { Taking Calculated Risks } \\
\text { and Being } \\
\text { Entrepreneurial }\end{array}$}} & & & & \\
\hline & & & & $\begin{array}{l}\text { Developing and } \\
\text { Maintaining } \\
\text { Interpersonal } \\
\text { Relationships }\end{array}$ & \multicolumn{2}{|c|}{$\begin{array}{l}\text { Turning Ideas into } \\
\text { Products, Processes, } \\
\text { and Services }\end{array}$} & $\begin{array}{c}\text { GISAT } 2.0 \text { (The } \\
\text { Conference Board of } \\
\text { Canada, 2013) }\end{array}$ \\
\hline $\begin{array}{c}\text { Idea } \\
\text { generation }\end{array}$ & & & $\begin{array}{c}\text { Idea } \\
\text { communication }\end{array}$ & $\begin{array}{l}\text { Implementation } \\
\text { starting activities }\end{array}$ & $\begin{array}{l}\text { Involving } \\
\text { others }\end{array}$ & $\begin{array}{l}\text { Overcoming } \\
\text { obstacles }\end{array}$ & Lukeš \& Stephan (2017) \\
\hline
\end{tabular}

Table 2. Models on Individual Innovation

Our own view of individual innovation competence departs from some of the features of the models above and gives rise to the model proposed in the following section of this study.

\section{Towards a Model of Individual Innovation Competence}

We agree with Marin-Garcia et al. (2016) that innovation competence is the ability to create, introduce, adapt and/or apply beneficial novelty at any organizational level. As a competence, innovation can be considered a cluster of separate or even overlapping competences, capacities and skills, which jointly can be regarded as innovation competence (Watts, García-Carbonell \& Andreu-Andrés, 2013). In seeking improved performance for the organization or group, innovation starts with the proposal and generation of new ideas and finishes with the use of the outcomes. Taking previous models as a starting point, our model integrates a two-dimensional model related to the two innovation phases by Dorenbosch et al. (2005) and other models that describe individual innovation 
(Cerinšek \& Dolinšek, 2009; Derksen et al., 2011; Evers, 2005; Kairisto-Mertanen et al., 2012; Lukeš \& Stephan, 2017; Marin-Garcia et al., 2013; Pérez-Peñalver, Watts, Marin-Garcia, Atarés-Huerta, Montero-Fleta, Aznar-Mas et al., 2016; The Conference Board of Canada, 2013; Waychal et al., 2011). For the first phase, creative-oriented work behaviour, we propose the dimensions of creativity and critical thinking, and for the second phase, the implementation phase, we propose the dimensions of initiative, teamwork and networking (Figure 2).

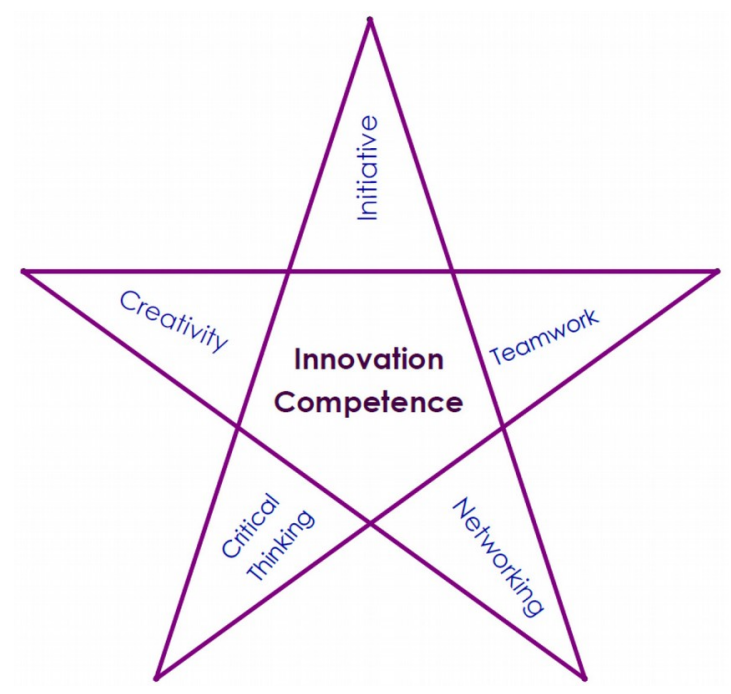

Figure 2. Proposed Model of Innovation Competence

This model is coherent with previous models found in the literature review. On the one hand, the factors most strongly associated with the first phase are individual and job level factors, and those most strongly associated with the implementation phase, are group and organizational factors (Axtell et al., 2000; Herzog \& Leker, 2010; West, 2002). As far as the generation phase is concerned, i.e. creativity and critical thinking, having a creative mind is especially important in idea generation; and persevering, having a communicative personality, being a task-oriented individual, being result-oriented and flexible are more important features in idea implementation (Caniëls et al., 2014).

\section{Influential studies for our research}

Previous to our classification, the following studies have to be highlighted because of their relevance in the framework of the present study:

- $\quad$ Kirton (1976): Kirton adaption-innovation inventory or KAI.

- Gough (1979). The creative personality scale for the Adjective Check List.

- Ettlie and O'Keefe (1982): 34 items to measure innovative behaviour or attitude toward being innovative.

- Amabile (1988): Model of individual creativity.

- Kanter (1988): Stages of innovation.

- Scott and Bruce (1994): Innovative behaviour measured with 6 items created by the authors, drawing on Kanter (1988).

- Anderson and West (1998): Team climate inventory, 38 item large version and 14 items the short version, to measure climate for group work innovation.

- Jansen (2000): 9 items to measure IWB, based on Scott \& Bruce (1994).

- Kleysen and Street (2001): 14 items created by the authors to measure IWB.

- George and Zhou (2001, 2002): Creative Performance Measure with 13 items, three of them adapted from Scott \& Bruce (1994).

- Dorenbosch et al. (2005): Innovative Work Behaviour Measure with 21 items created by the author. 
- De Jong and Den Hartog (2010): 10 items to measure IWB, initially 17, inspired by Janssen (2000); Kleysen and Street (2001), and Scott and Bruce (1994).

- De Spiegelaere et al. (2012, 2014): Measure 10 items from De Jong and Den Hartog (2010), and deepen in the concept, model and dimensions of IWB.

- Lukeš and Stephan (2017): Model of employee innovative behaviour with six dimensions and Innovative Behaviour Inventory with 23 items.

Additionally, other commercial products and current research projects should be mentioned as they intend to cover the area of assessment in innovation competence, particularly in organizations. Some online pay products have been devised to assess innovation as, e.g., The Innovation Potential Indicator (Patterson, 1999), General Innovation Skills Aptitude Test 2.0 (GISAT 2.0, by The Conference Board of Canada, 2013) or INNDUCE.ME (2014, with the collaboration of Ghent University). Some projects have also aimed at fostering and assessing innovation competence, e.g., INCODE (2011-2013), which created the INCODE Barometer (Marin-Garcia et al., 2013; Watts et al., 2013) and our present project (Aznar-Mas, Montero-Fleta, Pérez-Peñalver, Watts, García-Carbonell \& Marin-Garcia, 2015).

\section{Towards a Classification of Behavioural Indicators of Innovators}

This section will attempt to offer a classification of the behavioural indicators of innovation competence, according to the dimensions aforementioned. In a first stage of our literature review, all observable and measurable behavioural indicators were classified following the five dimensions. In a second stage, items measuring similar behaviours were grouped. Items showing an almost equal semantic content were included just once, but the different authors that used the items were cited.

The first phase of grouping behaviours includes creativity and critical thinking, corresponding to the idea generation phase, and the second one to the implementation phase which takes into account initiative, teamwork and networking.

\subsection{Creativity}

As aforementioned, Marin-Garcia et al. (2016) define creativity as the ability to think beyond existing ideas, rules, patterns or relationships. Creativity also involves the generating or adapting meaningful alternatives, ideas, products, methods or services regardless of possible practicality and future added value.

The individual behaviours found on this dimension were classified into the four main categories shown below: idea generation (Table 3), improvement (Table 4), problem solving (Table 5) and creative attitude (Table 6).

\section{Behavioural Indicators of Creativity_Category \#1}

\begin{tabular}{|l|l|}
\hline Presents novel ideas. & $\begin{array}{l}\text { Choi (2004); Choi, Sung, Lee and Dong-Sung (2011); Dewett (2006); } \\
\text { Frese and Fay (2001); George and Zhou (2001); Gupta (2011); Kim and } \\
\text { Lee (2013); Kirton (1976); Mumford and Gustafson (1988); Scott and } \\
\text { Bruce (1994); Shalley et al. (2009); Watts Marin-Garcia, García-Carbonell } \\
\text { and Aznar-Mas (2012) }\end{array}$ \\
\hline Is a good source of creative ideas & $\begin{array}{l}\text { Farmer, Tierney and Kung-McIntyre (2003); George and Zhou (2001, } \\
\text { 2002); Tierney, Farmer and Graen (1999) }\end{array}$ \\
\hline Generates ideas revolutionary to the field & Farmer et al. (2003); Gilson and Madjar (2011); Tierney et al. (1999) \\
\hline Generates ideas likely to deviate from the norm & Gupta (2011) \\
\hline Finds new ways to implement ideas & $\begin{array}{l}\text { De Jong and Den Hartog (2010); Watts, Marin-Garcia, García-Carbonell } \\
\text { and Aznar-Mas (2012) }\end{array}$ \\
\hline $\begin{array}{l}\text { Develops ideas that make existing knowledge } \\
\text { about current products/services obsolete }\end{array}$ & Baer (2012) \\
\hline
\end{tabular}




\section{Behavioural Indicators of Creativity_Category \#1}

\begin{tabular}{|l|l|}
\hline $\begin{array}{l}\text { Develops ideas that imply substantial departures } \\
\text { from existing product and service lines }\end{array}$ & Baer (2012) \\
\hline $\begin{array}{l}\text { Develops breakthrough ideas_-not minor } \\
\text { changes to existing products/services }\end{array}$ & Baer (2012) \\
\hline $\begin{array}{l}\text { Generates ideas on how to optimise knowledge } \\
\text { and skills }\end{array}$ & Dorenbosch et al. (2005) \\
\hline $\begin{array}{l}\text { Exhibits creativity on the job when given the } \\
\text { opportunity to }\end{array}$ & George and Zhou (2001, 2002) \\
\hline Often has new and innovative ideas & George and Zhou (2001, 2002) \\
\hline $\begin{array}{l}\text { Contributes to the firm with innovative ideas in a } \\
\text { commercial and/or social sense }\end{array}$ & Bulut, Samur and Halac (2011) \\
\hline $\begin{array}{l}\text { Takes risks in terms of producing new ideas in } \\
\text { doing job }\end{array}$ & Tierney et al. (1999) \\
\hline Finds new opportunities for innovation & Birdi et al. (2014) \\
\hline
\end{tabular}

Table 3. Behaviours showing "idea generation"

\section{Behavioural Indicators of Creativity_Category \#2}

Searches out new working methods, techniques or instruments
Birdi et al. (2014); Bysted (2013); Bysted and Hansen (2013); Chughtai (2013); De Jong and Den Hartog (2010); Dorenbosch et al. (2005); George and Zhou (2001, 2002); Janssen (2000); Kheng, June and Mahmood (2013); Kim and Lee (2013); Kim et al. (2009); Lukeš and Stephan (2017); Odoardi (2015); Oldham and Cummings (1996); Prieto and Pérez-Santana (2014); Ramamoorthy et al. (2005); Ruan, Hong and Jin (2010); Scott and Bruce (1994)

Makes suggestions to improve current process products or services

Bysted (2013); De Jong and Den Hartog (2010); Dewett (2006); Dorenbosch et al. (2005); George and Zhou (2001); The Conference Board of Canada (GISAT 2.0) (2013); Hilmi, Pawanchik, Mustapha and Mahmud (2012); Jokisaari and Vuori (2014); Kleysen and Street (2001); Parker, Williams and Turner (2006); Scott and Bruce (1994)

Comes up with new and practical ideas to improve performance

Uses new and worthwhile methods or work materials

Designs new procedures for work area

Thinks along concerning improvements in the work of direct colleagues

Develops ideas, methods, or products that are both original and useful to the organization

Suggests new ways to achieve goals or objectives

Suggests new ways to increase quality

Generates ideas concerning the distribution of tasks and work activities
Birdi et al. (2014); Bysted and Hansen (2013); De Jong and Den Hartog (2010); Dewett (2006); George and Zhou (2001, 2002); Ghafoor, Qureshi, Azeemi and Hijazi (2011); Jokisaari and Vuori (2014); Kim et al. (2009); Scott and Bruce (1994)

Dewett (2006); Ettlie and O’Keefe (1982); Ettlie, Groves, Vance and Hess (2014); George and Zhou (2001); Gilson and Madjar (2011); Scott and Bruce (1994); Tierney et al. (1999); Watts et al. (2012)

Parker et al. (2006)

Dorenbosch et al. (2005)

Ghafoor et al. (2011); Oldham and Cummings (1996); Tierney et al. (1999)

George and Zhou (2001, 2002); The Conference Board of Canada (GISAT 2.0) (2013); Kim et al. (2009)

George and Zhou (2001, 2002)

Dorenbosch et al. (2005) 


\section{Behavioural Indicators of Creativity_Category \#2}

\begin{tabular}{l|l|}
$\begin{array}{l}\text { Searches and uses existing information or } \\
\text { materials to develop ideas, methods, or products } \\
\text { that are useful to the organization }\end{array}$ & $\begin{array}{l}\text { Lukeš and Stephan (2017); Oldham and Cummings (1996); Tierney et al. } \\
(1999)\end{array}$ \\
\hline $\begin{array}{l}\text { Identifies opportunities for new products/ } \\
\text { processes }\end{array}$ & Tierney et al. (1999) \\
\hline Finds new areas for improvement & Birdi et al. (2014) \\
\hline
\end{tabular}

Table 4. Behaviours showing "improvement"

\section{Behavioural Indicators of Creativity_Category \#3}

Generates original solutions for problems or to opportunities
Amabile (1988); Bysted (2013); Chughtai (2013); Chughtai and Buckley (2011); De Jong and Den Hartog (2010); De Spiegelaere et al. (2012); Dewett (2006); Ettlie and O'Keefe (1982); Ettlie et al. (2014); Ford (1996); George and Zhou (2001); Gilson and Madjar (2011); Gorgievski, Moriano and Baker (2014); Gupta (2014); Hilmi et al. (2012); Janssen (2000); Kanter (1988); Kheng et al. (2013); Kirton (1976); Kleysen \& Street (2001); Lukeš (2013); Odoardi (2015); Ruan et al. (2010); Scott and Bruce (1994); Tierney et al. (1999); Truss, Conway, d'Amato, Kelly, Monks, Hannon et al.. (2012); Van de Ven (1986)

Tries to approach with new ideas or methods to solve a certain problem

Axtell et al. (2000); Choi (2004); Dorenbosch et al. (2005); Ettlie and O'Keefe (1982); Ettlie et al. (2014); Farmer et al. (2003); George and Zhou (2002); Gupta (2011); Lukeš and Stephan (2017); Tierney et al. (1999)

Often has a fresh approach to problems Farmer et al. (2003); Frese and Fay (2001); George and Zhou (2002); Kirton (1976)

Creates new ideas for difficult issues
Bulut et al. (2011); Chughtai (2013); Janssen (2000); Kheng et al. (2013); Odoardi (2015); Ramamoorthy et al. (2005); Ruan et al. (2010)

Table 5. Behaviours showing "problem-solving"

\begin{tabular}{|l|l|}
\hline \multicolumn{2}{|c|}{ Behavioural Indicators of Creativity_Category \#4 } \\
\hline Approaches challenges creatively & The Conference Board of Canada (GISAT 2.0) (2013) \\
\hline Demonstrates originality & $\begin{array}{l}\text { Ettlie and O’Keefe (1982); Ettlie et al. (2014); Frese and Fay (2001); } \\
\text { Ghafoor et al. (2011); Tierney et al. (1999) }\end{array}$ \\
\hline $\begin{array}{l}\text { Is always trying to do things differently from } \\
\text { before }\end{array}$ & Birdi et al. (2014); Lukeš and Stephan (2017) \\
\hline Acquires new knowledge frequently & De Jong and Den Hartog (2010) \\
\hline Puts forward his/her own ideas with confidence & The Conference Board of Canada (GISAT 2.0) (2013) \\
\hline
\end{tabular}

Table 6. Behaviours showing "creative attitude"

\subsection{Critical Thinking}

Critical thinking plays a crucial role in innovation. According to Bailin (1987: page 25) "Innovation must be viewed in terms of creating products which are not simply novel but also of value, and critical judgment is crucially involved in such creative achievement. In any creative solution to a problem, the initial recognition that there is a problem to be solved, the identification of the nature of the problem, and the determination of how to proceed all involve critical assessment".

Marin-Garcia et al. (2016) define critical thinking as the ability to analyse issues, evaluate advantages and disadvantages, and estimate the risks involved for a purpose. 
The individual behaviours found on this dimension were classified into the five main categories shown below: thinking differently (Table 7), analysing and identifying (Table 8), globalising (Table 9), evaluating (Table 10) and foreseeing (Table 11).

\section{Behavioural Indicators of Critical Thinking_Category \#1}

\begin{tabular}{|l|l|}
\hline Thinks outside the box & Ettlie and O'Keefe (1982); Gino and Wiltermuth (2014) \\
\hline Challenges others' points of view & Goldberg (1999) \\
\hline Uses divergent thinking & Gino and Wiltermuth (2014) \\
\hline Asks questions that nobody else does & Goldberg (1999); Kleysen and Street (2001) \\
\hline Is able to bring up problems and tough issues & Carmeli et al. (2010) \\
\hline
\end{tabular}

Table 7. Behaviours showing "thinking differently"

\begin{tabular}{|l|l|}
\hline \multicolumn{2}{|c|}{ Behavioural Indicators of Critical Thinking_Category \#2 } \\
\hline Analyses a long-term problem to find a solution & Parker et al. (2006) \\
\hline Finds out the root cause of a problem & Birdi et al. (2014); Kleysen and Street (2001) \\
\hline $\begin{array}{l}\text { Is able to pick the best option from a number of } \\
\text { solutions to a problem }\end{array}$ & Birdi et al. (2014) \\
\hline $\begin{array}{l}\text { Acknowledges when he/she doesn't know something } \\
\text { and takes steps to find out }\end{array}$ & Syracuse University Performance Partnership (2016) \\
\hline Identifies problems & Syracuse University Performance Partnership (2016); Gupta, (2014) \\
\hline Is good at identifying problems and potential solutions & The Conference Board of Canada (GISAT 2.0) (2013) \\
\hline
\end{tabular}

Table 8. Behaviours showing "analysing and identifying"

\section{Behavioural Indicators of Critical Thinking_Category \#3}

Identifies relationships among different components $\quad$ Watts et al. (2012)

of the task

Maintains a global perspective of the task

Can easily link facts together

Integrates multiple perspectives or combines ideas or materials from different modules in a constructive manner

\begin{tabular}{l|l} 
Redefines posed problems & Gupta (2011)
\end{tabular}

Table 9. Behaviours showing "globalizing"

\section{Behavioural Indicators of Critical Thinking_Category \#4}

\begin{tabular}{|l|l|}
\hline $\begin{array}{l}\text { Evaluates the advantages and disadvantages of actions } \\
\text { or ideas }\end{array}$ & $\begin{array}{l}\text { Chughtai (2013); Janssen (2000); Kleysen and Street (2001); } \\
\text { Ramamoorthy et al. (2005); Watts et al. (2012) }\end{array}$ \\
\hline Provides written evaluations of proposed ideas & Ettlie and O'Keefe (1982); Ettlie et al. (2014) \\
\hline Evaluates the utility of innovative ideas & Janssen (2000); Odoardi (2015); Ramamoorthy et al. (2005) \\
\hline $\begin{array}{l}\text { Evaluates solutions in order to make } \\
\text { recommendations or decisions }\end{array}$ & The Conference Board of Canada (GISAT 2.0) (2013) \\
\hline
\end{tabular}

Table 10. Behaviours showing "evaluating" 


\section{Behavioural Indicators of Critical Thinking_Category \#5}

\begin{tabular}{|l|l|}
\hline Forecasts how events will develop & $\begin{array}{l}\text { Janssen (2000); Prieto et al. (2014); Scott and Bruce (1994); Watts et } \\
\text { al. (2012) }\end{array}$ \\
\hline $\begin{array}{l}\text { Measures the impacts of a solution on performance, } \\
\text { productivity and financial results }\end{array}$ & $\begin{array}{l}\text { Bulut et al. (2011); The Conference Board of Canada (GISAT 2.0) } \\
(2013)\end{array}$ \\
\hline
\end{tabular}

Table 11. Behaviours showing "foreseeing"

\subsection{Initiative}

Initiative is a concept related with Personal Initiative (PI), which involves, Self-Starting, Pro-Active, and Persisting (Frese \& Fay, 2001; Frese, Kring, Soose \& Zempel, 1996). PI describes a class of active behaviours positively associated with innovation and entrepreneurial orientation and is directly linked to effective performance in organisations (Frese \& Fay, 2001; Patterson et al., 2009). Research suggests that PI is particularly important in the idea implementation phase (Patterson et al., 2009).

Marin-Garcia et al. (2016) define initiative as the ability to make decisions or take actions to operationalise ideas that foster positive changes, to influence creative people and those who have to implement the ideas.

The individual behaviours found on this dimension were classified into the six main categories shown below: moving others to act (Table 12), mobilising important partners (Table 13), organising the implementation of the work (Table 14), implementing the ideas (Table 15), assuming no common tasks and acceptable risks (Table 16) and being persistent and active (Table 17).

Behavioural Indicators of Initiative_Category \#1

\begin{tabular}{|l|l|}
\hline Motivates others to act & $\begin{array}{l}\text { The Conference Board of Canada (GISAT 2.0) (2013); } \\
\text { Watts et al. (2012) }\end{array}$ \\
\hline Promotes and champions ideas to others at work & Scott \& Bruce (1994) \\
\hline Encourages individuals and teams to bring forward new ideas & The Conference Board of Canada (GISAT 2.0) (2013) \\
\hline Tries to get new ideas from colleagues or business partners & Lukeš (2013); Lukeš \& Stephan (2017) \\
\hline
\end{tabular}

Table 12. Behaviours showing "moving others to act"

\section{Behavioural Indicators of Initiative_Category \#2}

\begin{tabular}{|l|l|}
$\begin{array}{l}\text { Convinces people to support an } \\
\text { innovative idea }\end{array}$ & $\begin{array}{l}\text { Berdrow and Evers (2011); Chughtai (2013); De Jong and Den Hartog (2008); } \\
\text { De Jong and Den Hartog (2010); De Spiegelaere et al. (2012); Globocnik and } \\
\text { Salomo (2014); Hilmi et al. (2012); Janssen (2000, 2001); Kanter (1988); Kirton } \\
(1976) ; \text { Kleysen and Street (2001); Lukeš and Stephan (2017) }\end{array}$ \\
\hline Mobilizes support for innovative ideas & $\begin{array}{l}\text { Bulut et al. (2011); Chughtai (2013); De Jong and Den Hartog (2008); } \\
\text { Dorenbosch et al. (2005); George and Zhou (2002); Gupta (2011, 2014); } \\
\text { Hormiga, Hancock and Valls-Pasola (2013); Hsiao, Chang, Tu and Chen (2011); } \\
\text { Janssen (2000, 2001); Kheng et al. (2013); Lukeš (2013); Madrid et al. (2014); } \\
\text { Odoardi (2015); Ramamoorthy et al. (2005); Ruan et al. (2010) }\end{array}$ \\
\hline $\begin{array}{l}\text { Makes organizational members } \\
\text { enthusiastic for innovative ideas }\end{array}$ & $\begin{array}{l}\text { Bulut et al. (2011); Chughtai (2013); De Jong and Den Hartog (2008); De Jong } \\
\text { and Den Hartog (2010); Dorenbosch et al. (2005); Globocnik and Salomo } \\
\text { (2014); Hormiga et al. (2013); Hsiao et al. (2011); Janssen (2000, 2001); Kheng et } \\
\text { al. (2013); Odoardi (2015); Ramamoorthy et al. (2005); Ruan et al. (2010) }\end{array}$ \\
\hline $\begin{array}{l}\text { Investigates and secures funds needed to } \\
\text { implement new ideas }\end{array}$ & $\begin{array}{l}\text { Ettlie and O’Keefe (1982); Ettlie et al. (2014); Kim and Lee (2013); Lukeš and } \\
\text { Stephan (2017); Scott and Bruce (1994) }\end{array}$ \\
\hline Makes ideas heard with confidence & \begin{tabular}{l} 
Luthans, Avolio, Avey and Norman (2007) \\
\hline
\end{tabular}
\end{tabular}

Table 13. Behaviours showing "mobilising important partners" 


\section{Behavioural Indicators of Initiative_Category \#3}

\begin{tabular}{|l|l|}
\hline Works towards goals & Luthans et al. (2007); Watts et al. (2012) \\
\hline $\begin{array}{l}\text { Uses an action-based approach: develops goals, collects } \\
\text { information, makes plans for executing them }\end{array}$ & $\begin{array}{l}\text { De Spiegelaere et al. (2012); George and Zhou (2001, 2002); } \\
\text { Kim and Lee (2013); Lukeš (2013); Lukeš and Stephan } \\
\text { (2017); Patterson et al. (2009); Scott and Bruce (1994) }\end{array}$ \\
\hline Plans for contingencies and is ready with alternative strategies & The Conference Board of Canada (GISAT 2.0) (2013) \\
\hline Fosters improvements in work organization & De Jong and Den Hartog (2010) \\
\hline
\end{tabular}

Table 14. Behaviours showing "organising the implementation of the work"

\begin{tabular}{|c|c|}
\hline \multicolumn{2}{|c|}{ Behavioural Indicators of Initiative_Category \#4 } \\
\hline $\begin{array}{l}\text { Leads new ideas from development to complete } \\
\text { a profitable reality }\end{array}$ & $\begin{array}{l}\text { Cerinšek and Dolinšek (2009); De Jong (2004); Hilmi et al. (2012); Kleysen } \\
\text { and Street (2001) }\end{array}$ \\
\hline $\begin{array}{l}\text { Transforms innovative ideas into useful } \\
\text { applications }\end{array}$ & $\begin{array}{l}\text { Chughtai (2013); Gorgievski et al. (2014); Hilmi et al. (2012); Hormiga et } \\
\text { al. (2013); Hsiao et al. (2011); Janssen (2000, 2001); Kheng et al. (2013); } \\
\text { Madrid et al. (2014); Ruan et al. (2010); Odoardi (2015); Truss et al. (2012) }\end{array}$ \\
\hline Takes action to realize new ideas & $\begin{array}{l}\text { Bulut et al. (2011); De Jong and Den Hartog (2008); De Jong and Den } \\
\text { Hartog (2010) }\end{array}$ \\
\hline Makes things happen if he/she believes in them & $\begin{array}{l}\text { Bateman and Crant (1993); Chen (2011); Lukeš (2013); Parker et al. (2006); } \\
\text { Seibert, Crant and Kraimer (1999) }\end{array}$ \\
\hline $\begin{array}{l}\text { Puts a lot of energy into coming up with new } \\
\text { ideas at work }\end{array}$ & $\begin{array}{l}\text { Birdi et al. (2014); Dorenbosch et al. (2005); The Conference Board of } \\
\text { Canada (GISAT 2.0) (2013); Lukeš and Stephan (2017) }\end{array}$ \\
\hline $\begin{array}{l}\text { Loves being a champion for his/her ideas, even } \\
\text { against others' opposition }\end{array}$ & $\begin{array}{l}\text { Bateman and Crant (1993); Chen (2011); Lukeš and Stephan (2017); Parker } \\
\text { et al. (2006); Seibert et al. (1999) }\end{array}$ \\
\hline $\begin{array}{l}\text { Takes action to insure the adoption of the new } \\
\text { product }\end{array}$ & Nelson et al. (2010) \\
\hline $\begin{array}{l}\text { Systematically introduces new ideas into work } \\
\text { practices }\end{array}$ & $\begin{array}{l}\text { Bulut et al. (2011); Chughtai (2013); De Jong and Den Hartog (2008); De } \\
\text { Spiegelaere et al. (2012); Hormiga et al. (2013); Hsiao et al. (2011); Janssen } \\
\text { (2000, 2001); Kheng et al. (2013); Kleysen and Street (2001); Odoardi } \\
\text { (2015); Ramamoorthy et al. (2005); Ruan et al. (2010); }\end{array}$ \\
\hline Implements changes that seem to be beneficial & Kleysen and Street (2001) \\
\hline
\end{tabular}

Table 15. Behaviours showing "implementing the ideas"

\section{Behavioural Indicators of Initiative_Category \#5}

\begin{tabular}{|l|l|}
\hline $\begin{array}{l}\text { Goes beyond expectations in the assignment, task, or } \\
\text { job description without being asked }\end{array}$ & Syracuse University Performance Partnership (2016) \\
\hline $\begin{array}{l}\text { Engages in activities that have a chance of not } \\
\text { working out }\end{array}$ & Hormiga et al. (2013) \\
\hline Takes an acceptable level of risk to support new ideas & $\begin{array}{l}\text { Bulut et al. (2011); Choi (2004); Dewett (2006); Ettlie and O'Keefe } \\
(1982) ; \text { George and Zhou (2001, 2002); Hilmi et al. (2012); Prieto } \\
\text { and Pérez-Santana (2014); Watts et al. (2012) }\end{array}$ \\
\hline Takes the initiative to realize new products/services & Globocnik and Salomo (2014) \\
\hline $\begin{array}{l}\text { Uses own methods of doing and is creative to get jobs } \\
\text { done }\end{array}$ & Bulut et al. (2011) \\
\hline Accepts empowerment to carry out a task & Globocnik and Salomo (2014) \\
\hline
\end{tabular}

Table 16. Behaviours showing "assuming no common tasks and acceptable risks" 


\section{Behavioural Indicators of Initiative_Category \#6}

\begin{tabular}{|c|c|}
\hline Has resilience, recovers readily & $\begin{array}{l}\text { The Conference Board of Canada (GISAT 2.0) (2013); Lukeš and } \\
\text { Stephan (2017); Luthans et al. (2007); Watts et al. (2012) }\end{array}$ \\
\hline $\begin{array}{l}\text { Learns from his/her experiences and is not afraid to } \\
\text { make mistakes }\end{array}$ & The Conference Board of Canada (GISAT 2.0) (2013) \\
\hline Acts quickly and energetically & $\begin{array}{l}\text { Atwater and Carmeli (2009); Carmeli and Spreitzer (2009); Ettlie and } \\
\text { O'Keefe (1982) }\end{array}$ \\
\hline $\begin{array}{l}\text { Puts a lot of energy into coming up with new ideas } \\
\text { at work }\end{array}$ & $\begin{array}{l}\text { Birdi et al. (2014); Dorenbosch et al. (2005); The Conference Board of } \\
\text { Canada (GISAT 2.0) (2013); Lukeš and Stephan (2017) }\end{array}$ \\
\hline $\begin{array}{l}\text { Persists in the face of possible resistance to his/her } \\
\text { ideas }\end{array}$ & Sternberg, (2006); Lukeš and Stephan (2017) \\
\hline
\end{tabular}

Table 17. Behaviours showing "being persistent and active"

\subsection{Teamwork}

Teamwork is a key determinant of innovation (Amabile, 1996; Ancona, Bresman \& Kaeufer, 2002; Pearce \& Ensley, 2004), and is most strongly associated with the implementation phase (Axtell et al., 2000; Herzog \& Leker, 2010; West, 2002).

For Marin-Garcia et al. (2016) teamwork is the ability to work effectively with others in a group (based on Stevens \& Campion, 1994; Pearce \& Ensley, 2004).

The individual behaviours found on this dimension were classified into the two main categories shown below: working well with others (Table 18) and making the team work well (Table 19).

\section{Behavioural Indicators of Teamwork_Category \#1}

\begin{tabular}{|c|c|}
\hline Attempts to share information throughout the team & $\begin{array}{l}\text { Anderson and West (1998); Anderson et al. (2014); Bulut et al. } \\
\text { (2011); Burch, Pavelis and Port (2008); Chen (2011); Choi (2004) }\end{array}$ \\
\hline $\begin{array}{l}\text { Interacts effectively with others to facilitate the } \\
\text { gathering, integrating and conveying of information in } \\
\text { many forms }\end{array}$ & $\begin{array}{l}\text { Anderson and West (1998); Berdrow and Evers (2011); Chen } \\
\text { (2011); Choi (2004); Dorenbosch et al. (2005); Watts et al. (2012) }\end{array}$ \\
\hline Invites feedback and comments & $\begin{array}{l}\text { Anderson and West (1998); Anderson et al. (2014); Carmeli and } \\
\text { Spreitzer (2009); Chen (2011); De Jong and Den Hartog (2010); } \\
\text { Watts et al. (2012) }\end{array}$ \\
\hline $\begin{array}{l}\text { Gives considerable opportunities for independence and } \\
\text { freedom to the other team members }\end{array}$ & Carmeli and Spreitzer (2009); De Jong and Den Hartog (2010) \\
\hline $\begin{array}{l}\text { Encourages, mentors, and coaches others to share ideas } \\
\text { and speak freely }\end{array}$ & The Conference Board of Canada (GISAT 2.0) (2013) \\
\hline $\begin{array}{l}\text { Coordinates the work of others and encourages positive } \\
\text { group relationships }\end{array}$ & $\begin{array}{l}\text { Anderson et al. (2014); Berdrow and Evers (2011); Dekas, Bauer, } \\
\text { Welle, Kurkoski and Sullivan (2013) }\end{array}$ \\
\hline $\begin{array}{l}\text { Makes it easy for people to collaborate and deliver new } \\
\text { solutions }\end{array}$ & The Conference Board of Canada (GISAT 2.0) (2013) \\
\hline $\begin{array}{l}\text { Identifies sources of conflict between his/herself and } \\
\text { others, or among other people, and to take steps to } \\
\text { overcome disharmony }\end{array}$ & Berdrow and Evers (2011); Watts et al. (2012) \\
\hline Sets clear expectations to team members & Choi (2004); Rousseau, Aube and Tremblay (2013) \\
\hline Identifies team weaknesses & Dekas et al. (2013); Rousseau et al. (2013) \\
\hline Gives suggestions to the team & $\begin{array}{l}\text { Anderson and West (1998); Burch and Anderson (2004); Chen } \\
\text { (2011); Dekas et al. (2013); Rousseau et al. (2013) }\end{array}$ \\
\hline
\end{tabular}




\section{Behavioural Indicators of Teamwork_Category \#1}

\begin{tabular}{|l|l|}
\hline Stimulates problem solving in the team & $\begin{array}{l}\text { Dewett (2006); Ettlie and O'Keefe (1982); Ettlie et al. (2014); } \\
\text { Rousseau et al. (2013); Scott and Bruce (1994) }\end{array}$ \\
\hline $\begin{array}{l}\text { Meets team members frequently to talk both formally } \\
\text { and informally }\end{array}$ & $\begin{array}{l}\text { Anderson and West (1998); Burch and Anderson (2004); Chen } \\
(2011)\end{array}$ \\
\hline
\end{tabular}

Table 18. Behaviours showing "working well with others"

Behavioural Indicators of Teamwork_Category \#2

\begin{tabular}{|c|c|}
\hline Conveys ideas successfully & $\begin{array}{l}\text { Anderson and West (1998); Chen (2011); Choi (2004); Dekas et al. } \\
\text { (2013); Watts et al. (2012) }\end{array}$ \\
\hline $\begin{array}{l}\text { Provides constructive feedback, cooperation, coaching } \\
\text { or help to team colleagues }\end{array}$ & $\begin{array}{l}\text { Chen (2011); Dekas et al. (2013); Dorenbosch et al. (2005); The } \\
\text { Conference Board of Canada (GISAT 2.0) (2013); Schepers and } \\
\text { Van den Berg (2007) }\end{array}$ \\
\hline Consults about essential changes & De Jong and Den Hartog (2010); Pearce and Ensley (2004) \\
\hline Obtains constructive comments from colleagues & $\begin{array}{l}\text { Bysted (2013); Dekas et al. (2013); Schepers and Van den Berg } \\
\text { (2007) }\end{array}$ \\
\hline $\begin{array}{l}\text { Works well with others, understanding their needs and } \\
\text { being sympathetic with them }\end{array}$ & $\begin{array}{l}\text { Anderson and West (1998); Berdrow and Evers (2011); Chen } \\
\text { (2011) }\end{array}$ \\
\hline $\begin{array}{l}\text { Co-operates in order to help develop and apply new } \\
\text { ideas }\end{array}$ & $\begin{array}{l}\text { Anderson and West (1998); Burch and Anderson (2004); Chen } \\
\text { (2011) }\end{array}$ \\
\hline $\begin{array}{l}\text { Respects and supports the ideas, approaches, and } \\
\text { contributions of others }\end{array}$ & The Conference Board of Canada (GISAT 2.0) (2013) \\
\hline $\begin{array}{l}\text { Is attentive when others are speaking, and responds } \\
\text { effectively to others' comments during the conversation }\end{array}$ & $\begin{array}{l}\text { Anderson and West (1998); Berdrow and Evers (2011); Chen } \\
\text { (2011); Choi (2004); Watts et al. (2012) }\end{array}$ \\
\hline Accepts team decisions, even if in disagreement & Anderson and West (1998); Chen (2011); Dekas et al. (2013) \\
\hline Shows flexibility when working in collaboration & $\begin{array}{l}\text { Anderson and West (1998); Anderson et al. (2014); West and Farr } \\
\text { (1990) }\end{array}$ \\
\hline Interacts frequently in the team & $\begin{array}{l}\text { Anderson and West (1998); Burch and Anderson (2004); Chen } \\
\text { (2011); Dekas et al. (2013) }\end{array}$ \\
\hline Understands and accepts team members & $\begin{array}{l}\text { Anderson and West (1998); Burch and Anderson (2004); Chen } \\
\text { (2011) }\end{array}$ \\
\hline
\end{tabular}

Table 19. Behaviours showing "making the team work well"

\subsection{Networking}

The success of the implementation of an idea depends on the ability to persuade powerful and influential people of the value of innovation. Innovators need colleagues outside their own organization for informational and emotional social support. Then a social network for innovators facilitates the innovation process (De Jong, 2004; Nelson et al., 2010).

For Ferris, Treadway, Kolodinsky, Hochwarter, Kacmar, Douglas et al. (2005) and Baer (2012) networking ability is likely to allow people to cultivate different types of social relationships and network constellations. Perry-Smith and Shalley (2003) suggest that we need to empirically explore the social side of individual innovation in which (external) network contacts occur. Furthermore, De Jong and Den Hartog (2010) found that external work contacts were positively and significantly related to IWB, thus, it seems to be crucial to study the social network of the employees.

For Marin-Garcia et al. (2016) networking is the ability to involve stakeholders outside the team. 
The individual behaviours found on this dimension were classified into the four main categories shown below: making the necessary contacts for a project (Table 20), making contacts out of an organization (Table 21), working well in different contexts (table 22) and miscellaneous (Table 23).

\section{Behavioural Indicators of Networking_Category \#1}

\begin{tabular}{l|l} 
Identifies the appropriate decision makers and & Frese and Fay (2001); Lukeš and Stephan (2017; Watts et al. (2012)
\end{tabular} stakeholders who have the power to make a difference

Engages outsiders of the core work group from the beginning

George and Zhou (2001, 2002); Parker et al. (2006); Scott and Bruce (1994)

Shares timely information with the appropriate stakeholders

De Jong and Den Hartog (2008); Janssen (2000); Kleysen and Street (2001); Parker et al. (2006); Scott and Bruce (1994)

Shows diplomacy and skill in managing situations with $\quad$ Lukeš (2013) different stakeholders

Works together with outsiders to provide benefits to the team/organization

Ferris et al. (2005)

Table 20. Behavioural indicators showing "making the necessary contacts for a project"

\section{Behavioural Indicators of Networking_Category \#2}

Builds relationships outside the team/ organization

Ettlie and O’Keefe (1982); Ettlie et al. (2014); Ferris et al. (2005); Frese and Fay (2001); The Conference Board of Canada (GISAT 2.0) (2013)

Acquires, assimilates, transforms and exploits external knowledge to establish, manages and learns from De Jong and Den Hartog (2008); Frese and Fay (2001); Janssen (2000); Kleysen and Street (2001); Lukeš (2013); Patterson et al. (2009); Scott and Bruce (1994)

informal organisational ties

Chen (2011); De Jong and Den Hartog (2010); Dyer, Gregensen

Meets people with different kinds of ideas and perspectives to extend his/her own knowledge domains and Christensen (2009); The Conference Board of Canada (GISAT 2.0) (2013)

Visits conferences, trade fairs and/or expositions

De Jong and Den Hartog (2010)

Talks to people from other companies in the market

De Jong and Den Hartog (2010)

Keeps in touch with people from universities/knowledge institutions

De Jong and Den Hartog (2008); De Jong and Den Hartog (2010); Janssen (2000); Kleysen and Street (2001); Scott and Bruce (1994)

Makes a conscious effort to visit other countries and meet people from other walks of life

De Jong and Den Hartog (2010); Dyer, Gregersen and Christensen (2009)

Table 21. Behavioural indicators showing "making contacts out of an organization"

\section{Behavioural Indicators of Networking_Category \#3}

\begin{tabular}{|l|l|}
\hline Works in multidisciplinary environments & Frese and Fay (2001); Watts et al. (2012) \\
\hline Works in multicultural environments & Ettlie and O'Keefe (1982); Watts et al. (2012) \\
\hline
\end{tabular}

Table 22. Behavioural indicators showing "working well in different contexts"

\section{Behavioural Indicators of Networking_Category \#4}

Contacts people outside the company (e.g., customers) $\quad$ Bysted (2013); Parker et al. (2006)

to discuss problems

Visits external customers

De Jong and Den Hartog (2008); De Jong and Den Hartog (2010); Janssen (2000); Kleysen and Street (2001); Scott and Bruce (1994)

Chooses communication channels with different Bjorklund, Bhatli and Laakso (2013) 


\section{Behavioural Indicators of Networking_Category \#4}

\begin{tabular}{|l|l|}
\hline parties & \\
\hline $\begin{array}{l}\text { Takes the opportunity to translate communications } \\
\text { from other departments for his/her work group }\end{array}$ & Ettlie and O'Keefe (1982); Ettlie et al. (2014) \\
\hline $\begin{array}{l}\text { Uses personal contacts to manoeuvre his/herself into } \\
\text { choice work assignments }\end{array}$ & Ettlie and O'Keefe (1982); Ettlie et al. (2014) \\
\hline
\end{tabular}

Table 23. Miscellaneous

\section{Conclusions}

The majority of the models in the literature describe several dimensions of the construct but, generally speaking, none of these models is based on any publication in scientific papers following a strict, complex validation process replicated by researchers (Marin-Garcia et al., 2016). There is a lack of publications containing a detailed analysis of the dimensionality of the models based on multi-item measurements (Marin-Garcia, Ramírez Bayarri \& Atarés-Huerta, 2015). Our research focused on the existing models in the literature about individual innovation and our model integrates both the generation and the implementation phases, where creativity and critical thinking are associated to generation; conversely, initiative, teamwork and networking are associated to the implementation phase.

The first contribution was the identification of the behavioural indicators of innovators at the workplace. To describe the capacity of individual innovators at the workplace, our literature review confirmed the presence of closely related concepts with blurred boundaries between them. The most relevant concepts in our research to detect the innovative behaviour of innovators are Innovative Work Behaviour and Innovation Competence. The behavioural indicators obtained will allow us to assess, self-assess and develop the innovation competence of individuals. We have sought to offer a better understanding of the phenomenon of individual innovation in organisations, an issue that has not been studied from this perspective in previous studies, according to the results of our systematic literature review.

The second contribution was the classification of the behavioural indicators of innovators according to the model of innovation competence presented here. Our classification may be useful to design further tools to measure innovation competence of future professionals. On the one hand, our study fills a void that may be useful to HR Departments of organizations to value the potential of innovation in recruitment and selection processes, or management of individual innovators. On the other hand, it may be of special interest to universities to develop and measure the innovation competence of undergraduates (Lehto, Kairisto-Mertanen \& Penttilä, 2011). This interest lays on the fact that universities are urgently required to transform the learning methodologies and assessment strategies if they want to provide society with qualified professionals for the future. Not only academic formation is required but also competences that may allow the development of innovation in organizations and companies (Marin-Garcia et al., 2013).

Based on the results of the study, our avenue for future research is the piloting of a tool to measure innovation competence and to validate the model proposed. Next, it would be of interest to verify the value that organizations give to this tool as well as analyse the user's perspective on the tool. This is our ongoing process to yield some light on the assessment of innovative workplace performance in organisations, as well as on the development and assessment of the innovative competence of students in academic institutions (Marin-Garcia et al., 2015), as a challenge to meet the needs of both professionals and Higher Education institutions.

\section{Declaration of Conflicting Interests}

The authors declare no potential conflicts of interest with respect to the research, authorship, and/or publication of this article. 


\section{Funding}

This research has been supported by the Erasmus+ Project FINCODA (2015-2017). Framework for Innovation Competences Development and Assessment_554493-EPP-1-2014-1-FI-EPPKA2-KA (The European Commission support for the production of this publication does not constitute an endorsement of the contents which reflects the views only of the authors, and the Commission cannot be held responsible for any use which may be made of the information contained therein) and by the Project PIME 2015-2016 A/09_Evaluación de los indicadores del comportamiento innovador en el alumno universitario, at the Universitat Politècnica de València (Spain).

\section{References}

Abbas, M., \& Raja, U. (2015). Impact of psychological capital on innovative performance and job stress. Canadian Journal of Administrative Sciences/Revue Canadienne Des Sciences de l'Administration, 32(2), 128-138. https://doi.org/10.1002/cjas.1314

Agarwal, U.A. (2014). Examining the impact of social exchange relationships on innovative work behaviour. Team Performance Management: An International Journal, 20(3/4), 102-120. https://doi.org/10.1108/TPM-01-2013-0004

Amabile, T.M. (1983). The social psychology of creativity: A componential conceptualization. Journal of Personality and Social Psychology, 45(2), 357-376. https://doi.org/10.1037/0022-3514.45.2.357

Amabile, T.M. (1988). A model of creativity and innovation in organizations. Research in Organizational Behaviour, 10(1), 123-167.

Amabile, T.M. (1996). The motivation for creativity in organizations. Harvard Business Review, January, 5(9), 1-14.

Amo, B.W. (2006). What motivates knowledge workers to involve themselves in employee innovation behaviour? International Journal of Knowledge Management Studies, 1(1/2), 160-177. https://doi.org/10.1504/IJKMS.2006.008851

Ancona, D., Bresman, H. \& Kaeufer, K. (2002). The comparative advantage of X-teams. MIT Sloan Management Review, 43(3), 33-39.

Anderson, N.R., \& West, M.A. (1998). Measuring climate for work group innovation: development and validation of the team climate inventory. Journal of Organizational Behaviour, 19(3), 235-258.

https://doi.org/10.1002/(SICI)1099-1379(199805)19:3<235::AID-JOB837>3.0.CO;2-C

Anderson, N., Potočnik, K., \& Zhou, J. (2014). Innovation and Creativity in Organizations: A State-of-the-Science Review, Prospective Commentary, and Guiding Framework. Journal of Management, 40(5), 1297-1333. https://doi.org/10.1177/0149206314527128

Arias-Galicia L. F., \& Heredia-Espinosa, V. (2006). Administración de Recursos Humanos para el Alto Desempeño (6a ed.). México: Trillas.

Atwater, L., \& Carmeli, A. (2009). Leader-member exchange, feelings of energy, and involvement in creative work. The Leadership Quarterly, 20(3), 264-275. https://doi.org/10.1016/j.leaqua.2007.07.009

Axtell, C.M., Holman, D.J., Unsworth, K.L., Wall, T.D., Waterson, P.E., \& Harrington, E. (2000). Shopfloor innovation: Facilitating the suggestion and implementation of ideas. Journal of Occupational and Organizational Psychology, 73(3), 265-285. https://doi.org/10.1348/096317900167029

Aznar-Mas, L.E., Montero-Fleta, B., Pérez-Peñalver, M.J., Watts, F., García-Carbonell, A., \& Marin-Garcia, J.A. (2015). De Proyecto INCODE a FINCODA: utilización del Barómetro INCODE en alumnos universitarios y en empleados con competencias de innovación. Conference proceedings InRed 2015 (1197-1206). Universitat Politècnica de València, Spain. https://doi.org/10.4995/INRED2015.2015.1620 
Aznar-Mas, L.E., Pérez-Peñalver, M.J., Montero-Fleta, B., González-Ladrón de Guevara, F., Marin-Garcia, J. A., \& Atarés-Huerta, L.M. (2016). Indicadores de comportamiento de la competencia de innovación en el ámbito académico y en el profesional: revisión de la literatura. Conference proceedings InRed 2016 (1257-1268). Universitat Politècnica de València, Spain. https://doi.org/10.4995/INRED2016.2016.4389

Baer, M. (2012). Putting Creativity to Work: The Implementation of Creative Ideas in Organizations. Academy of Management Journal, 55(5), 1102-1119. https://doi.org/10.5465/amj.2009.0470

Bailin, S. (1987). Critical and creative thinking. Informal Logic, 9(1), 23-30. https://doi.org/10.22329/il.v9i1.2656

Bălău, G., Faems, D., \& van der Bij, H. (2012). Individual Characteristics and Their Influence on Innovation: A Literature Review. Proceedings of the 9Th International Conference on Innovation and Management (887-901).

Bateman, T.S., \& Crant, J., (1993). The Proactive Component of Organizational behaviour: A Measure and Correlates. Journal of Organizational Behaviour, 14(2), 103-118.https://doi.org/10.1002/job.4030140202

Batra, S., \& Vohra, N. (2016) Exploring the linkages of cognitive style and individual innovativeness. Management Research Review, 39(7), 768-785. https://doi.org/10.1108/MRR-03-2014-0047

Berdrow, I., \& Evers, F.T. (2011). Bases of competence: A framework for facilitating reflective learner-centered educational environments. Journal of Management Education, 35(3), 406-427.

https://doi.org/10.1177/1052562909358976

Birdi, K., Leach, D., \& Magadley, W. (2014). The relationship of individual capabilities and environmental support with different facets of designers' innovative behaviour. Journal of Product Innovation Management, 33(1), 19-35. https://doi.org/10.1111/jpim.12250

Bjorklund, T., Bhatli, D., \& Laakso, M. (2013). Understanding idea advancement efforts in innovation through proactive behaviour. Journal of Research in Marketing and Entrepreneurship, 15(2), 124-142. https://doi.org/10.1108/JRME-01-2013-0001

Bos-Nehles, A., Renkema, M., \& Janssen, M. (2017). HRM and innovative work behaviour: a systematic literature review. Personnel Review, 46(7), 1228-1253. https://doi.org/10.1108/PR-09-2016-0257

Bulut, C., Samur, S.B., \& Halac, D.S. (2011). Does Really Innovative Work Behaviours of Employees Mediate the Innovative Performance Impacts of Intrapreneurship? Fulford, H. (Ed.) Proceedings of the 6th European Conference on Innovation and Entrepreneurship, 1(2), 173-182.

Burch, G.S.J., \& Anderson, N. (2004). Measuring person-team fit: Development and validation of the team selection inventory. Journal of Managerial Psychology, 19(4), 406-426. https://doi.org/10.1108/02683940410537954

Burch, G.S.J., Pavelis, C., \& Port, R.L. (2008). Selecting for Creativity and Innovation: The relationship between the innovation potential indicator and the team selection inventory. International Journal of Selection and Assessment, 16(2), 177-181. https://doi.org/10.1111/j.1468-2389.2008.00422.x

Bysted, R. (2013). Innovative employee behaviour: the moderating effects of mental involvement and job satisfaction on contextual variables. European Journal of Innovation Management, 16(3), 268-284.

https://doi.org/10.1108/EJIM-09-2011-0069

Bysted, R., \& Hansen, J.J.R. (2013). Comparing Public and Private Sector Employees' Innovative Behaviour: Understanding the role of job and organizational characteristics, job types, and subsectors. Public Management Review, 17(5), 698-717. https://doi.org/10.1080/14719037.2013.841977

Caniëls, M.C.J., De Stobbeleir, K., \& De Clippeleer, I. (2014). The Antecedents of Creativity Revisited: A Process Perspective. Creativity and Innovation Management, 23(2), 96-110. https://doi.org/10.1111/caim.12051

Carmeli, A., \& Spreitzer, G.M. (2009). Trust, connectivity, and thriving: implications for innovative behaviours at work. Journal of Creative Behaviour, 43(3), 169-191. https://doi.org/10.1002/j.2162-6057.2009.tb01313.x

Carmeli, A., Meitar, R., \& Weisberg, J. (2006). Self-leadership skills and innovative behaviour at work. International Journal of Manpower, 27(1), 75-90. https://doi.org/10.1108/01437720610652853 
Carmeli, A., Reiter-Palmon, R., \& Ziv, E. (2010). Inclusive Leadership and Employee Involvement in Creative Tasks in the Workplace: The Mediating Role of Psychological Safety. Creativity Research Journal, 22(3), 250-260. https://doi.org/10.1080/10400419.2010.504654

Cerinšek, G., \& Dolinšek, S. (2009). Identifying employees' innovation competency in organisations. International Journal of Innovation and Learning, 6(2), 164-177. https://doi.org/10.1504/IJIL.2009.022811

Chen, W.J. (2011). Innovation in hotel services: Culture and personality. International Journal of Hospitality Management, 30(1), 64-72.https://doi.org/10.1016/j.ijhm.2010.07.006

Choi, J.N. (2004). Individual and contextual dynamics of innovation-use behaviour in organizations. Human Performance, 17(4), 397-414. https://doi.org/10.1207/s15327043hup1704_3

Choi, J.N., Sung, S.Y., Lee, K., \& Dong-Sung, C. (2011). Balancing cognition and emotion: Innovation implementation as a function of cognitive appraisal and emotional reactions toward innovation. Journal of Organizational Behaviour, 32(1), 107-124. https://doi.org/10.1002/job.684

Chughtai, A.A. (2013). Linking affective commitment to supervisor to work outcomes. Journal of Managerial Psychology, 28(6), 606-627. https://doi.org/10.1108/JMP-09-2011-0050

Chughtai, A.A., \& Buckley, F. (2011). Work engagement antecedents, the mediating role of learning goal orientation and job performance. Career Development International, 16(6-7), 684-705. https://doi.org/10.1108/13620431111187290

Cruz-Serna, A.V., Orozco-Jaramillo, Á.M., Varela-Gaviria, G., Trespalacios-Bustos, J.I., Zapata-Arboleda, J.A., Bustamante-Osorio, M.A., et al. (2012). Competencias gerenciales del directivo docente, para el ejercicio efectivo de la gerencia educativa. Identificación, descripción y metodologias para su desarrollo. (Trabajo de Grado). Facultad de Educación. Universidad de San Buenaventura, Medellín (Colombia).

De Jong, J.P.J. (2004). How can leaders trigger bottom-up innovation? An Empirical Research into Knowledge Intensive Services. SCALES SCientific AnaLysis of Entrepreneurship and SMEs, May, 1-53.

De Jong, J.P.J. (2016). Entrepreneurial Behavior by Employees in Organizations. Available in SSRN. https://doi.org/10.2139/ssrn.2721615

De Jong, J.P.J., \& Den Hartog, D.N. (2007). How leaders influence employees' innovative behaviour. European Journal of Innovation Management, 10(1), 41-64. https://doi.org/10.1108/14601060710720546

De Jong, J.P.J., \& Den Hartog, D.N. (2008). Innovative work behaviour, measurement and validation. SCALES SCientific AnaLysis of Entrepreneurship and SMEs, 1-27.

De Jong, J.P.J., \& Den Hartog, D. (2010). Measuring Innovative Work Behaviour. Creativity and Innovation Management, 19(1), 23-36. https://doi.org/10.1111/j.1467-8691.2010.00547.x

De Spiegelaere, S., Van Gyes, G., \& Van Hootegem, G. (2014). The Innovative Work Behaviour concept: definition and orientation (Translated from: Innovatief werkgedrag als concept: definiëring en orienteering. Gedrag \& Organisatie 27(2), 139-156).

https://www.researchgate.net/publication/285946970 The concept of Innovative Work Behavior Definition and orient $\underline{\text { ation }}$

De Spiegelaere, S., Van Gyes, G., \& Van Hootegem, G. (2016). Not All Autonomy is the Same. Different Dimensions of Job Autonomy and Their Relation to Work Engagement \& Innovative Work Behavior. Human Factors and Ergonomics in Manufacturing, 26(4) 515-527. https://doi.org/10.1002/hfm.20666

De Spiegelaere, S., Van Gyes, G., Van Thillo, T., \& Van Hootegem, G. (2012). Innovative Work Behaviour: Concept \& Measurement. ISPIM Conference Proceedings. Barcelona, Spain.

Dekas, K.H., Bauer, T.N., Welle, B., Kurkoski, J., \& Sullivan, S. (2013). Organizational Citizenship Behaviour, Version 2.0: A review and Qualitative Investigation of OCBs for Knowledge Workers at Google and beyond. The Academy of Management Perspectives, 27(3), 219-237. https://doi.org/10.5465/amp.2011.0097 
Dent, S.M., \& Krefft, J.H. (2004). Powerhouse Partners: A Blueprint for Building Organizational Culture for Breakaway Results. California: Davies Black Publishing.

Derksen, K., de Caluwé, L., \& Simons, R.J. (2011). Developmental space for groups working on innovation. Human Resource Development International, 14(3), 253-271. https:/ / doi.org/10.1080/13678868.2011.585060

Dewett, T. (2006). Exploring the role of risk in employee creativity. Journal of Creative Behaviour, 40(1), 27-45. https://doi.org/10.1002/j.2162-6057.2006.tb01265.x

Dorenbosch, L., van Engen, M.L., \& Verhagen, M. (2005). On-the-job Innovation: The Impact of Job Design and Human Resource Management through Production Ownership. Creativity and Innovation Management, 14(2), 129-141. https://doi.org/10.1111/j.1476-8691.2005.00333.x

Dyer, J.H., Gregersen, H.B., \& Christensen, C.M. (2009). The Innovator's DNA. Harvard Business Review, 87(12), 60-67.

Ettlie, J.E., \& O'Keefe, R.D. (1982). Innovative attitudes, values, and intentions in organizations (1). Journal of Management Studies. 19(2), 163-182. https://doi.org/10.1111/j.1467-6486.1982.tb00066.x

Ettlie, J.E.S., Groves, K.S., Vance, C.M., \& Hess, G.L. (2014). Cognitive style and innovation in organizations. European Journal of Innovation Management, 17(3), 311-326. https://doi.org/10.1108/EJIM-11-2012-0101

Evers, F.T. (2005). Bases of Competence Skills Porfolio Specifications, (1-34). University of Guelph.

Farmer, S.M., Tierney, P., \& Kung-McIntyre, K. (2003). Employee creativity in Taiwan: An application of role identity theory. Academy of Management Journal, 46(5), 618-630. https:/ / doi.org/10.2307/30040653

Ferris, G.R., Treadway, D.C., Kolodinsky, R.W., Hochwarter, W.A., Kacmar, C.J., Douglas, C et al. (2005). Development and validation of the political skill inventory. Journal of Management, 31(1), 126-152. https://doi.org/10.1177/0149206304271386

Ferruzca-Navarro, M.V., Rodrigues-Martínez, J., Monguet-Fierro, J.M., \& Trejo-Omeñaca, A. (2013). Team equilibrium and innovation performance. IEEE Tsinghua International Design Management Symposium, IEEE (30-36). https://doi.org/10.1109/TIDMS.2013.6981212

FINCODA (2015-2017). Erasmus+ Project: Framework for Innovation Competences Development and Assessment. 554493-EPP-1-2014-1-FI-EPPKA2-KA. https://www.fincoda.eu

Ford, C.M. (1996). A theory of individual creative action in multiple social domains. Academy of Management Review, 21(4), 1112-1142.

Frese, M., \& Fay, D. (2001). Personal initiative: An active performance concept for work in the 21st century. Research in Organizational Behaviour, 23, 133-187. https://doi.org/10.1016/S0191-3085(01)23005-6

Frese, M., Kring, W., Soose, A., \& Zempel, J. (1996). Personal initiative at work: Differences between East and West Germany. Academy of Management Journal, 39(1), 37-63. https://doi.org/10.2307/256630

George, J.M., \& Zhou, J. (2001). When openness to experience and conscientiousness are related to creative behaviour: An interactional approach. Journal of Applied Psychology, 86(3), 513-524.

https://doi.org/10.1037/0021-9010.86.3.513

George, J.M., \& Zhou, J. (2002). Understanding when bad moods foster creativity and good ones don't: The role of context and clarity of feelings. Journal of Applied Psychology, 87(4), 687-697. https://doi.org/10.1037//00219010.87.4.687

Ghafoor, A., Qureshi, T.M., Azeemi, H.R., \& Tahir Hijazi, S. (2011). Mediating role of creative self-efficacy. African Journal of Business Management, 5(27), 11093-11103. https://doi.org/10.5897/AJBM11.876

Giebels, E., de Reuver, R.S.M., Rispens, S., \& Ufkes, E.G. (2016). The Critical Roles of Task Conflict and Job Autonomy in the Relationship Between Proactive Personalities and Innovative Employee Behavior. Journal of Applied Behavioural Science. 52(3), 320-341. https://doi.org/10.1177/0021886316648774 
Gilson, L.L., \& Madjar, N. (2011). Radical and incremental creativity: Antecedents and processes. Psychology of Aesthetics, Creativity, and the Arts, 5(1), 21-28. https://doi.org/10.1037/a0017863

Gino, F., \& Wiltermuth, S.S. (2014). Evil Genius? How Dishonesty Can Lead to Greater Creativity. Psychological Science, 25(4), 973-981. https://doi.org/10.1177/0956797614520714

Globocnik, D., \& Salomo, S. (2014). Do Formal Management Practices Impact the Emergence of Bootlegging Behaviour? Journal of Product Innovation Management, 32(4), 505-521. https://doi.org/10.1111/jpim.12215

Goldberg, L.R. (1999). A broad-bandwidth, public domain, personality inventory measuring the lower-level facets of several five-factor models. Personality Psychology in Europe, 7(1), 7-28.

González-Ladrón de Guevara, F., Watts, F., Andreu-Andrés, Mª.A., Aznar-Mas, L.E., Fernández, A., García-Carbonell, A., et al. (2011). Definition of Innovation Competences, University of Applied Sciences, Utrecbt, CARPE Consortium on Applied Research and Professional Education. Available at: http://www.carpenetwork.org/Networking $\% 20$ conference/Social\%20Innovations.aspx

Gorgievski, M.J., Moriano, J.A., \& Bakker, A.B. (2014). Relating work engagement and workaholism to entrepreneurial performance. Journal of Managerial Psychology, 29(2), 106-121. https://doi.org/10.1108/JMP-06-20120169

Gough, H.G. (1979). A creative personality scale for the Adjective Check List. Journal of Personality and Social Psychology, 37(8), 1398-1405. https://doi.org/10.1037/0022-3514.37.8.1398

Groth-Marnat, G. (2009). Handbook of psychological assessment. New York: John Wiley \& Sons.

Gupta, B. (2011). Organisational culture and creative behaviour: moderating role of creative style preference. International Journal of Innovation and Learning, 10(4), 429-441. https:/ / doi.org/10.1504/IJIL.2011.043100

Gupta, V. (2014). Psychological capital as a mediator of the relationship between leadership and creative performance behaviours: empirical evidence from the Indian R\&D sector. The International Journal of Human Resource Management, 25(10), 1373-1394. https://doi.org/10.1080/09585192.2013.870311

Hakimian, F., Farid, H., Ismail, M.N., \& Nair, P.K. (2016). Importance of commitment in encouraging employees' innovative behaviour. Asia-Pacific Journal of Business Administration, 8(1), 70-83. https://doi.org/10.1108/APJBA-062015-0054

Hammond, M.M., Neff, N.L., Farr, J.L., Schwall, A.R., \& Zhao, X. (2011). Predictors of individual-level innovation at work: A meta-analysis. Psychology of Aesthetics, Creativity, and the Arts, 5(1), 90-105.

https://doi.org/10.1037/a0018556

Herzog, P., \& Leker, J. (2010). Open and Closed Innovation: Different Cultures for Different Strategies. International Journal of Technology Management, 52(3/4). https://doi.org/10.1007/978-3-8349-8090-8

Hilmi, M.F., Pawanchik, S., Mustapha, Y., \& Mahmud, N. (2012). Innovative behaviour of Malaysian employees: An exploratory study. International Conference on Innovation Management and Technology Research, IEEE (135-138). Malacca, Malaysia. https://doi.org/10.1109/ICIMTR.2012.6236375

Hormiga, E., Hancock, C., \& Valls-Pasola, J. (2013). The relationship between employee propensity to innovate and their decision to create a company. Management Decision, 51(5), 938-953. https://doi.org/10.1108/MD-08-2012-0591

Hsiao, H.C., Chang, J.C., Tu, Y.L., \& Chen, S.C. (2011). The impact of self-efficacy on innovative work behaviour for teachers. International Journal of Social Science and Humanity, 1(1), 31-36. https://doi.org/10.7763/IJSSH.2011.V1.6

Hülsheger, U.R., Anderson, N., \& Salgado, J.F. (2009). Team-level predictors of innovation at work: a comprehensive meta-analysis spanning three decades of research. The Journal of Applied Psychology, 94(5), 11281145. https://doi.org/10.1037/a0015978

INCODE (2011-2013). Erasmus+ Project: Innovation Competencies Development. http://www.incode-eu.eu/en

INNDUCE.ME (2014). http://www.innduce.me/en 
Janssen, O. (2000). Job demands, perceptions of effort-reward fairness and innovative work behaviour. Journal of Occupational and Organizational Psychology, 73, 287-302. https://doi.org/10.1348/096317900167038

Janssen, O. (2001). Fairness perceptions as a moderator in the curvilinear relationships between job demands, and job performance and job satisfaction. Academy of Management Journal, 44(5), 1039-1050.

https://doi.org/10.2307/3069447

Janssen, O. (2004). How fairness perceptions make innovative behaviour more or less stressful. Journal of Organizational Behaviour, 25(2), 201-215. https://doi.org/10.1002/job.238

Janssen, O., \& Van Yperen, N.W. (2004). Employees' goal orientations, the quality of leader-member exchange, and the outcomes of job performance and job satisfaction. Academy of Management Journal, 47(3), 368-384. https://doi.org/10.2307/20159587

Jokisaari, M., \& Vuori, J. (2014). Joint effects of social networks and information giving on innovative performance after organizational entry. Journal of Vocational Behaviour, 85(3), 352-360. https://doi.org/10.1016/j.jvb.2014.08.007

Kairisto-Mertanen, L., Räsänen, M., Lehtonen, J., \& Lappalainen, H. (2012). Innovation Pedagogy - Learning through Active Multidisciplinary Methods. Revista de Docencia Universitaria. REDU. Monográfico: Buenas prácticas docentes en la enseñanza universitaria. 10(1), 67-86. https://doi.org/10.4995/redu.2012.6122

Kanter, R.M. (1988). When a thousand flowers bloom: Structural, collective, and social conditions for innovation in organization. Research in Organizational Behaviour, 10, 69-211.

Kheng, Y.K., June, S., \& Mahmood, R. (2013). The Determinants of Innovative Work Behaviour in the Knowledge Intensive Business Services Sector in Malaysia. Asian Social Science, 9(15), 47-59.

https://doi.org/10.5539/ass.v9n15p47

Kim, T.T., \& Lee, G. (2013). Hospitality employee knowledge-sharing behaviours in the relationship between goal orientations and service innovative behaviour. International Journal of Hospitality Management, 34(1), 324-337. https://doi.org/10.1016/j.ijhm.2013.04.009

Kim, T.Y., Hon, A.H. Y., \& Crant, J.M. (2009). Proactive Personality, Employee Creativity, and Newcomer Outcomes: A Longitudinal Study. Journal of Business and Psychology, 24(1), 93-103. https://doi.org/10.1007/s10869-009-9094-4

Kirton. M. (1976). Adaptors and Innovators; A description and a measure. Journal of Applied Psychology, 61(5), 622-629. https://doi.org/10.1037//0021-9010.61.5.622

Kleysen, R.F., \& Street, C.T. (2001). Toward a multi-dimensional measure of individual innovative behaviour. Journal of Intellectual Capital, 2(3), 284-296. https://doi.org/10.1108/EUM0000000005660

Kör, B. (2016). The mediating effects of self-leadership on perceived entrepreneurial orientation and innovative work behavior in the banking sector. SpringerPlus, 5(1): 1829. https://doi.org/10.1186/s40064-016-3556-8

Lehto, A., Kairisto-Mertanen, L., \& Penttilä, T. (2011). Towards Innovation Pedagogy. A new approach to teaching and learning for universities of applied sciences. Turku University of Applied Sciences.

Li, M., \& Hsu, C.H.C. (2016) A review of employee innovative behavior in services. International Journal of Contemporary Hospitality Management, 28(12), 2820-2841. https://doi.org/10.1108/IJCHM-04-2015-0214

Lipponen, J., Bardi, A., \& Haapamäki, J. (2008). The interaction between values and organizational identification in predicting suggestion-making at work. Journal of Occupational and Organizational Psychology, 81(2), 241-248. https://doi.org/10.1348/096317907X216658

Lukeš, M. (2013). Entrepreneurs as innovators: A multi-country study on entrepreneurs' innovative behaviour. Prague Economic Papers, (1), 72-84. https://doi.org/10.18267/j.pep.441

Lukeš, M., \& Stephan, U. (2017) Measuring employee innovation: A review of existing scales and the development of the innovative behaviour and innovation support inventories across cultures. International Journal of Entrepreneurial Behavior \& Research, 23(1), 136-158. https://doi.org/10.1108/IJEBR-11-2015-0262 
Luthans, F., Avolio, B.J., Avey, J.B., \& Norman, S.M. (2007). Positive Psychological Capital: Measurement and Relationship with Performance and Satisfaction. Personnel Psychology, 60, 541-572.

https://doi.org/10.1111/j.1744-6570.2007.00083.x

Madrid, H.P., Patterson, M.G., Birdi, K.S., Leiva, P.I., \& Kausel, E.E. (2014). The role of weekly high-activated positive mood, context, and personality in innovative work behaviour: A multilevel and interactional model. Journal of Organizational Behaviour, 35, 234-256. https://doi.org/10.1002/job.1867

Marin-Garcia, J.A., Aznar-Mas, L.E., \& González-Ladrón de Guevara, F. (2011). Innovation types and talent management for innovation. Working Papers on Operations Management, 2(2), 25-31.

https://doi.org/10.4995/wpom.v2i2.926

Marin-Garcia, J.A., Pérez-Peñalver, M.J., \& Watts, F. (2013). How to assess Innovation Competence in Services: The case of university students. Dirección y Organización, 50, 48-62.

Marin-Garcia, J.A., Ramírez Bayarri, L., \& Atarés-Huerta, L.M. (2015). Protocol: Comparing advantages and disadvantages of Rating Scales, Behaviour Observation Scales and Paired Comparison Scales for behaviour assessment of competencies in workers. A systematic literature review. WPOM-Working Papers on Operations Management, 6(2), 49-63. https://doi.org/10.4995/wpom.v6i2.4032

Marin-Garcia, J.A., Andreu-Andrés, Må.A., Atarés-Huerta, L., Aznar-Mas, L. E., García-Carbonell, A., González-Ladrón de Guevara, F., et al. (2016) Proposal of a Framework for Innovation Competencies Development and Assessment (FINCODA). Working Papers on Operations Management. https://doi.org/10.4995/wpom.v7i2.6472

Messmann, G., \& Mulder, R. (2011). Innovative work behaviour in vocational colleges: Understanding how and why innovations are developed. Vocations and Learning, 4, 63-84.https://doi.org/10.1007/s12186-010-9049-y

Montero-Fleta, B., Pérez-Peñalver, M.J., \& Aznar-Mas, L.E. (2017). Behavioural indicators of innovators. A search protocol for a systematic literature review. New Trends and Issues Proceedings on Humanities and Social Sciences, 1, 113-120. https://doi.org/10.18844/gihss.v3i1.1757

Muchinsky, P.M. (2006). Psychology applied to work: An introduction to industrial and organizational psychology (1). North Carolina: Thomson Wadsworth.

Mumford, M.D., \& Gustafson, S.B. (1988). Integration, application, and innovation. Psychological Bulletin,103(1), 27-43. https://doi.org/10.1037/0033-2909.103.1.27

Nelson, M., Brice, J., \& Gunby, N.W. Jr. (2010). Innovation adoption decisions: The effect of problem solving styles and social support. Journal of Organizational Culture, Communications and Conflict, 14(1), 73-88.

Ng, T.W.H., \& Feldman, D.C. (2013a). A meta-analysis of the relationships of age and tenure with innovation-related behaviour. Journal of Occupational and Organizational Psychology, 86, 585-616. https://doi.org/10.1111/joop.12031

Ng, T.W.H., \& Feldman, D.C. (2013a). Age and innovation-related behaviour: The joint moderating effects of supervisor undermining and proactive personality. Journal of Organizational Behaviour, 34, 583-606. https://doi.org/10.1002/job.1802

O’Brien, W.H., Oemig, C.K., \& Northern, J.J. (2010). Behavioural assessment with adults. Handbook of Clinical Psychology Competencies (283-308). Springer. https://doi.org/10.1007/978-0-387-09757-2_11

Odoardi, C. (2015). The relationship between proactive goal generation and innovative behaviour at work. Journal of Management Development, 34(5), 553-565. https://doi.org/10.1108/JMD-04-2014-0037

Oldham, G.R., \& Cummings, A. (1996). Employee creativity: Personal and contextual factors at work. Academy of Management Journal, 39(3), 607-634. https://doi.org/10.2307/256657

Parker, S.K., Williams, H.M., \& Turner, N. (2006). Modelling the antecedents of proactive behaviour at work. Journal of Applied Psychology, 91(3), 636-652. https://doi.org/10.1037/0021-9010.91.3.636 
Parzefall, M.R., Seeck, H., \& Leppänen, A. (2008). Employee innovativeness in organizations: a review of the antecedents. Finnish Journal of Business, 2(8), 165-182.

Patterson, F. (1999). The Innovation Potential Indicator. Manual and User's Guide. Oxford: OPP Ltd. https://www.opp.com/en/tools/Innovation-PI

Patterson, F., Kerrin, M., \& Gatto-Roissard, G. (2015). Characteristics and behaviours of innovative people in organisations. Available in NESTA. City University London. 1-64.

Patterson, F., Kerrin, M., Gatto-Roissard, G., \& Coan, P. (2009). Everyday innovation: How to enhance innovative working in employees and organisations (1-54). Available in NESTA. City University London.

Pearce, C.L., \& Ensley, M. (2004). A reciprocal and longitudinal investigation of the innovation process: The central role of shared vision in product and process innovation teams (PPITs). Journal of Organizational Behaviour, 25, 259-278. https://doi.org/10.1002/job.235

Pérez-Peñalver, M.J., Aznar-Mas, L.E., \& Watts, F. (2012). To adapt or to die when leaving the university: To promote innovation competence may be the key. Proceedings of INTED Conference (2731-2736). Valencia, Spain.

Pérez-Peñalver, M.J., Watts, F., Marin-Garcia, J.A., Atarés-Huerta, L., Montero-Fleta, B., Aznar-Mas, L.E., et al. (2016). Behavioural indicators of innovation competence. Proceedings of INTED Conference (8606-8611). Valencia, Spain. https://doi.org/10.21125/inted.2016.0998

Perry-Smith, J.E., \& Shalley, C.E. (2003). The Social Side of Creativity: A Static and Dynamic Social Network Perspective. The Academy of Management Review, 28(1), 89-106.

Pinchot III, G. (1985). Intrapreneuring: Why you don't have to leave the corporation to become an entrepreneur. New York: Harper-Row Publishers.

Prieto, I.M., \& Pérez-Santana, M.P. (2014). Managing innovative work behaviour: the role of human resource practices. Personnel Review, 43(2), 184-208. https://doi.org/10.1108/PR-11-2012-0199

Ramamoorthy, N., Flood, P.C., Slattery, T., \& Sardessai, R. (2005). Determinants of Innovative Work Behaviour: Development and Test of an Integrated Model. Creativity and Innovation Management, 14(2), 142-150. https://doi.org/10.1111/j.1467-8691.2005.00334.x

Rank, J., Pace, V.L., \& Frese, M. (2004). Three avenues for future research on creativity, innovation, and initiative. Applied Psychology, 53(4), 518-528. https://doi.org/10.1111/j.1464-0597.2004.00185.x

Reuvers, M., van Engen, M.L., Vinkenburg, C.J., \& Wilson-Evered, E. (2008). Transformational Leadership and Innovative Work Behaviour: Exploring the Relevance of Gender Differences. Creativity and Innovation Management, 17(3), 227-244. https://doi.org/10.1111/j.1467-8691.2008.00487.x

Rousseau, V., Aube, C., \& Tremblay, S. (2013). Team coaching and innovation in work teams. An examination of the motivational and behavioural intervening mechanisms. Leadership \& Organization Development Journal, 34(4), 344364. https://doi.org/10.1108/LODJ-08-2011-0073

Ruan, A., Hong, W., \& Jin, J. (2010). The impact of motivation on employee innovative behaviour and the disparity analysis: An empirical study of Zhejiang Province in China. IEEE International Conference on Management of Innovation \& Technology, IEEE (652-657). https://doi.org/10.1109/ICMIT.2010.5492741

Schepers, P., \& van den Berg, P.T. (2007). Social factors of work-environment creativity. Journal of Business and Psychology, 21(3), 407-428. https://doi.org/10.1007/s10869-006-9035-4

Schroeder, R., Van de Ven, A. H., Scudder, G. D., \& Polley, D. (1989). The development of innovation ideas. In Ven, A.H. van de, Angle, H.L., \& Poole, M.S. (Eds.). Research on the management of innovation: The Minnesota studies (107-134). New York: Harper \& Row.

Scott, S.G., \& Bruce, R.A. (1994). Determinants of innovative behaviour: A path model of individual innovation in the workplace. Academy of Management Journal, 37(3), 580-607. https://doi.org/10.2307/256701 
Seibert, S.E., Crant, J.M., \& Kraimer, M.L. (1999). Proactive personality and career success. Journal of Applied Psychology, 84(3), 416-427. https://doi.org/10.1037/0021-9010.84.3.416

Shalley, C.E., Gilson, L.L., \& Blum, T.C. (2009). Interactive Effects of Growth Need Strength, Work Context, and Job Complexity on Self-Reported Creative Performance. Academy of Management Journal, 52(3), 489-505. https://doi.org/10.5465/AMJ.2009.41330806

Slåtten, T., \& Mehmetoglu, M. (2011). Antecedents and effects of engaged employees. A study from the hospitality industry. Managing Service Quality, 21(1), 88-107. https://doi.org/10.1108/09604521111100261

Sternberg, R.J. (2006). Creating a vision of creativity: The first 25 years. Psychology of Aesthetics, Creativity, and the Arts, 1, 2-12. https://doi.org/10.1037/1931-3896.S.1.2

Stevens, M.J., \& Campion, M.A. (1994). The knowledge, skill, and ability requirements for teamwork: Implications for human resource management. Journal of management, 20(2), 503-530.

https://doi.org/10.1177/014920639402000210

Syracuse University Performance Partnership (2016). A guide for identifying and discussing performance behaviors for successful job performance. http://performance.syr.edu/competency-library/\#innovation

The Conference Board of Canada (2013). Education and Learning. General Innovation Skills Aptitude Test (GISAT 2.0). http://www.conferenceboard.ca/topics/education/learning-tools.aspx

Thurlings, M., Evers, A.T., \& Vermeulen, M. (2014). Toward a Model of Explaining Teachers' Innovative Behaviour A Literature Review. Review of Educational Research, 85(3), 430-471. https://doi.org/10.3102/0034654314557949

Tierney, P., Farmer, S.M., \& Graen, G.B. (1999). An Examination of Leadership and Employee Creativity: The Relevance of Traits and Relationships. Personnel Psychology, 52(3), 591-620. https://doi.org/10.1111/j.17446570.1999.tb00173.x

Truss, C., Conway, E., d’Amato, A., Kelly, G., Monks, K., Hannon, E. et al. (2012). Knowledge work: gender-blind or gender-biased? Work, Employment \& Society, 26(5), 735-754. https://doi.org/10.1177/0950017012451675

Van de Ven, A.H. (1986). Central Problems in the Management of Innovation. Management Science, 32(5), $590-607$. https://doi.org/10.1287/mnsc.32.5.590

Watts, F., García-Carbonell, A., \& Andreu-Andrés, M.A. (2013). Innovation competencies development: INCODE Barometer and user guide. Turku: Turku University of Applied Sciences.

Watts, F., Marin-Garcia, J. A., García-Carbonell, A., \& Aznar-Mas. L.E. (2012). Validation of a rubric to assess innovation competence. Working Papers on Operations Management, 3(1), 61-70.

https://doi.org/10.4995/wpom.v3i1.1159

Waychal, P., Mohanty, R.P., \& Verma, A. (2011). Determinants of innovation as a competence: an empirical study. International Journal of Business Innovation and Research, 5(2), 192.https://doi.org/10.1504/IJBIR.2011.038781

West, M.A. (2002). Sparkling Fountains or Stagnant Ponds: An Integrative Model of Creativity and Innovation Implementation in Work Groups. Applied Psychology, 51(3), 355-387. https://doi.org/10.1111/1464-0597.00951

West, M.A., \& Farr, J.L. (1989). Innovation at work: Psychological perspectives. Social Behaviour, 4(1), 15-30.

West, M.A., \& Farr, J.L. (1990). Innovation and creativity at work: Psychological and organizational strategies. Oxford: John Wiley \& Sons.

Widmann, A., Messmann, G., \& Mulder, R.H. (2016). The Impact of Team Learning Behaviors on Team Innovative Work Behavior: A Systematic Review. Human Resource Development Review, 15(4), 429-458. https://doi.org/10.1177/1534484316673713

Wiethe-Körprich, M., Weber, S., Bley, S., \& Kreuzer, C. (2017). Intrapreneurship Competence as a Manifestation of Work Agency: A Systematic Literature Review. In Goller, M., \& Paloniemi, S. (Eds.). Agency at Work. Professional and Practice-based Learning (20, 373-399). Cham: Springer. https://doi.org/10.1007/978-3-319-60943-0_3 
Woodman, R.W., Sawyer, J.E., \& Griffin, R.W. (1993). Toward a theory of organizational creativity. Academy of Management Review, 18(2), 293-321.

Yuan, F., \& Woodman, R.W. (2010). Innovative behaviour in the workplace: The role of performance and image outcome expectations. Academy of Management Journal, 53(2), 323-342. https://doi.org/10.5465/AMJ.2010.49388995

Zhou, J., \& Shalley, C.E. (2003). Research on employee creativity: A critical review and directions for future research. Research in Personnel and Human Resources Management, 22, 165-217. https://doi.org/10.1016/S07427301(03)22004-1

Zhu, H., Djurjagina, K., \& Leker, J. (2014). Innovative Behaviour Types and Their Influence on Individual Crowdsourcing Performances. International Journal of Innovation Management, 18(06), 1440015 (18 pages). https://doi.org/10.1142/S1363919614400155

Journal of Industrial Engineering and Management, 2018 (www.jiem.org)

\section{(c) (1) (3)}

Article's contents are provided on an Attribution-Non Commercial 4.0 Creative commons International License. Readers are allowed to copy, distribute and communicate article's contents, provided the author's and Journal of Industrial Engineering and Management's names are included. It must not be used for commercial purposes. To see the complete license contents, please visit https://creativecommons.org/licenses/by-nc/4.0/. 